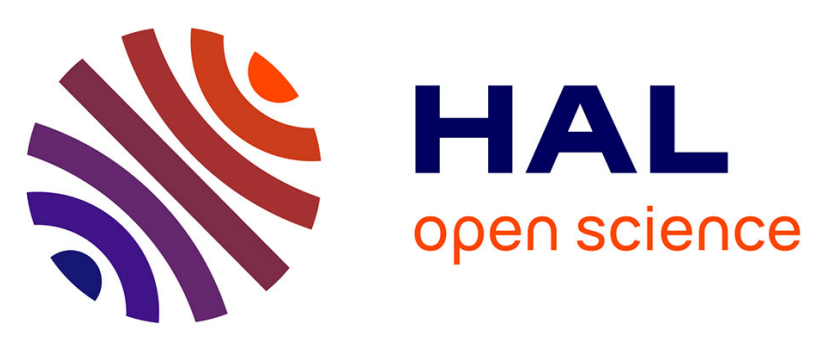

\title{
Biocompatible and stable magnetosome minerals coated with poly- 1 -lysine, citric acid, oleic acid, and carboxy-methyl-dextran for application in the magnetic hyperthermia treatment of tumors
}

Chalani Mandawala, Imène Chebbi, Mickael Durand-Dubief, Raphael Le

Fèvre, Yasmina Hamdous, François Guyot, Edouard Alphandéry

\section{To cite this version:}

Chalani Mandawala, Imène Chebbi, Mickael Durand-Dubief, Raphael Le Fèvre, Yasmina Hamdous, et al.. Biocompatible and stable magnetosome minerals coated with poly- 1 -lysine, citric acid, oleic acid, and carboxy-methyl-dextran for application in the magnetic hyperthermia treatment of tumors. Journal of materials chemistry B, 2017, 10.1039/C6TB03248F . hal-01586778

\section{HAL Id: hal-01586778 \\ https://hal.sorbonne-universite.fr/hal-01586778}

Submitted on 13 Sep 2017

HAL is a multi-disciplinary open access archive for the deposit and dissemination of scientific research documents, whether they are published or not. The documents may come from teaching and research institutions in France or abroad, or from public or private research centers.
L'archive ouverte pluridisciplinaire HAL, est destinée au dépôt et à la diffusion de documents scientifiques de niveau recherche, publiés ou non, émanant des établissements d'enseignement et de recherche français ou étrangers, des laboratoires publics ou privés. 
1 Biocompatible and stable magnetosome minerals coated

2 with poly-L-lysine, citric acid, oleic acid, and carboxymethyl-dextran, for application in the magnetic hyperthermia treatment of tumors. Hamdous $^{1,4}$, François Guyot ${ }^{2}$, Edouard Alphandéry ${ }^{1,2, *}$

${ }^{2}$ Institut de minéralogie et de physique des Matériaux et de Cosmochimie, UMR 7590 CNRS, Sorbonne Universités, Muséum National d'Histoire Naturelle, Université Pierre et Marie Curie, IRD, 61 rue Buffon, 75005, Paris, France.

${ }^{4}$ Laboratoire d'Imagerie et Modélisation en Neurobiologie et Cancérologie, Campus Universitaire, Bât. ${ }^{3}$ Equipe de Paléomagnétisme, Institut de Physique du Globe de Paris, Paris Cité, Université Paris 
Magnetic hyperthermia, in which magnetic nanoparticles are introduced into tumors and exposed to an

21 alternating magnetic field (AMF), appears promising since it can lead to increased patients life

22 expectancy. Its efficacy can be further improved by using biocompatible iron oxide magnetosome

23 minerals with better crystallinity and magnetic properties compared with chemically synthesized

24 nanoparticles (IONP - Iron Oxide Nanoparticles). To fabricate such minerals, magnetosomes are first

25 isolated from MSR-1 magnetotactic bacteria, purified to remove potentially toxic organic bacterial

26 residues and stabilized with poly-L-lysine (N-PLL), citric acid (N-CA), oleic acid (N-OA), or carboxy-

27 methyl-dextran (N-CMD). The different coated nanoparticles appear to be composed of a cubo-

28 octahedral mineral core surrounded by a coating of various thickness, composition, and charge, and to

29 be organized in chains of various lengths. In vitro anti-tumor and heating efficacy of these

30 nanoparticles were examined by bringing them into contact with GL-261 glioblastoma cells and by

31 applying an AMF. This led to a specific absorption rate of 89-196 W/gFe, measured using an AMF of

$32198 \mathrm{kHz}$ and $34-47 \mathrm{mT}$, and to a percentage of tumor cell destruction due to nanoparticles exposed to

33 AMF of $10 \pm 3 \%$ to $43 \pm 3 \%$ depending on the coating agent. It indicated the potential of these

34 nanoparticles for the magnetic hyperthermia tumor treatment.

\section{KEYWORDS}

36 Magnetosomes, magnetotactic bacteria, magnetosome minerals, minerals, magnetic hyperthermia,

37 alternating magnetic field.

38

39 
INTRODUCTION

For more than a decade, magnetic nanoparticles are widely used for several biomedical applications, $(1,2)$, such as gene, drug and radionuclide delivery, magnetic bio-separation, (3), magnetic resonance imaging, MRI, and for the magnetic hyperthermia treatment of tumors carried out both in vitro, (4), (5), and in vivo on animals, (6), (7), and humans, (8). This treatment has proven its efficacy for glioblastoma treatment, (9), leading to an average survival time of 13 months following diagnosis, compared with 4 to 6 months with conventional treatments, (Maier-Hoff2007 et Maier-Hoff 2010).

Magnetic hyperthermia is considered as a nontoxic approach to cancer therapy, in which biological tissues are exposed to moderate temperatures of $43^{\circ} \mathrm{C}$ to $46^{\circ} \mathrm{C}$ allowing selective destruction of tumor cells, (11). In magnetic hyperthermia, magnetic nanoparticles are usually administered to tumors and heated several times by applying an alternating magnetic field of strength 5-20 mT and frequency $50-200 \mathrm{kHz}$, (12). Most of the tested nanoparticles are chemically synthesized superparamagnetic iron oxide nanoparticles, SPION, (13). In this study, we introduce another type of iron oxide nanoparticles, which is synthesized by a strain of magnetotactic bacteria, MTB, called MSR1 Magnetospirillum gryphiswaldense. MTB were originally discovered by Salvatore Bellini in 1963, (14), and reintroduced by Richard Blakmore in 1975, (15). MTB synthesize intracellular magnetic nanoparticles, called magnetosomes, whose magnetic moments align parallel to the earth magnetic field, (16). Magnetosomes act as a compass to guide magnetotactic bacteria in the direction of the earth magnetic field, (17). They are made of a crystallized mineral core composed of magnetite $\left(\mathrm{Fe}_{3} \mathrm{O}_{4}\right)$, which is surrounded by an organic layer, (18), (19). They are usually organized in chains, preventing their aggregation, a property which is not usually found among chemical nanoparticles. Moreover, due to their sizes of 30 to $120 \mathrm{~nm}$, high level of crystallinity, ferrimagnetic properties, they heat more efficiently than most chemically synthesized nanoparticles under application of high frequency 
magnetic fields, (20). The efficacy of magnetosomes isolated from MTB has already been demonstrated and the concept of evidence established on a murine model with breast cancer, (21). However, the previously tested magnetosome suspensions, which did not undergo any specific treatment, contained pyrogenic endotoxins, which need to be removed for further use in a medicinal preparation, (22).

In this article, we describe a method to produce magnetosome minerals, from which the organic layer originating from MTB has been mostly removed, and which thus contains very low endotoxin concentrations while organizing in stable suspensions. In this method, magnetosomes are extracted from MTB and treated chemically to remove most of the organic material surrounding magnetosome minerals. To prevent their aggregation, magnetosome minerals are then coated with the four following biocompatible coating agents, which have already been used for the stabilization of chemically synthesized nanoparticles: i), poly-L-lysine, PLL, (23), ii), citric acid, CA, (24), iii), oleic acid, OA, (25), (26), or, iv), carboxy-methyl-dextran, CMD, (27). The properties of these coated magnetosome minerals, such as endotoxin concentration, coating thickness, possible arrangement in chains, cytotoxicity tested according to ISO 10993-5, in vitro heating, internalization and antitumor efficacy under the application of an AMF are examined and compared with those of pyrogenic magnetosome chains directly extracted from magnetotactic bacteria, MC, and Iron Oxide Nanoparticles (IONP), which are chemically synthesized and currently used for the magnetic hyperthermia treatment of cancer, $(11,28)$. We decided to use IONP since: i) they are ferrimagnetic iron oxide nanoparticles similar in composition and magnetic properties to the magnetosomes but with lower values of coercivity and Mr/Ms (valeurs à reprendre de l'article de Raphael?), (Branquinho and al. (2013), Kasten and al (2014), Zadnik and al (2014)), ii) they are commonly used in the study of magnetic hyperthermia (ToryanaBrown). Since coated magnetosomes are intended to be used on humans, we have followed regulatory guidelines (ISO 10993 standards) for the assessment of their biocompatibility. 
Materials

Iron Oxide Nanoparticles (IONP). IONP (10-00-102), which are starch coated magnetite nanoparticles, were purchased from Micromod Partikeltechnologie, GmbH, Rostock, Germany. We estimated that IONP contain an endotoxin concentration of $140 \mathrm{EU} / \mathrm{ml}$ per mg of iron.

Growth of MSR-1 magnetotactic bacteria. Magnetospirillum gryphiswaldense strain MSR-1 (DSM6361) was purchased from Deutsche Sammlung von Mikro-organismen und Zellkulturen (Brunswick, Germany). First, MSR-1 cells are deposited on solid activated charcoal agar medium, and incubated at $29{ }^{\circ} \mathrm{C}$ under microaerobic conditions during 7 days, (29). Then, several black-brown colonies are collected from the solid agar medium, containing (completer) and are cultivated and amplified at $29^{\circ} \mathrm{C}$ under stirring. Cells are then introduced in a $35 \mathrm{~L}$ fermentation medium, containing in $1 \mathrm{~L}$ of medium $118 \mathrm{ml}$ of $85 \%$ lactic acid, $18 \mathrm{ml}$ of $25 \%$ to $28 \%$ ammonia, $2.4 \mathrm{~g}$ of magnesium sulfate, $6 \mathrm{~g}$ of potassium phosphate, $0.2 \mathrm{ml}$ of propylene glycol, $6 \mathrm{~g}$ of yeast extract and $7 \mathrm{ml}$ of mineral elixir (30). Fermentation is carried out at $29-30{ }^{\circ} \mathrm{C}$ under agitation at $200 \mathrm{rpm}$ during 5 days. During fermentation, $\mathrm{pH}$ is maintained at 6.9 by adding an acidic feeding medium containing an iron source. Growth of magnetotactic bacteria is stimulated by bubbling oxygen in the growth medium. Temperature, agitation speed, $\mathrm{pH}$, feeding pump flow and oxygen concentration, are monitored and adjusted using an EZ controller and a BioXpert software from Applikon Biotechnology.

Magnetosomes isolated from magnetotactic bacteria, MC. After fermentation, MSR-1 cells are concentrated and washed in water using tangential flow filtration. To lyse the bacteria and obtain a suspension containing pyrogenic chains of $\mathrm{MC}$, concentrated MSR-1 cells are resuspended in 5M $\mathrm{NaOH},(31)$, and heated at $60{ }^{\circ} \mathrm{C}$ during 2 hours. Then they are sonicated four times in the presence of a solution of PBS $1 \mathrm{X}$ at $10 \mathrm{~W}$ during $20 \mathrm{sec}$, to remove all lysis bacterial cells remains (32). 
113 are re-suspended in a solution containing $1 \%$ Triton X-100 and $1 \%$ SDS and are then heated at $50{ }^{\circ} \mathrm{C}$ 114 overnight; (ii), they are mixed in phenol at $\mathrm{pH} 8$ and then heated at $60{ }^{\circ} \mathrm{C}$ during 2 hours in a $25 \mathrm{KHz}$ 115 sonicating bath (SB); (iii), they are re-suspended in chloroform and heated at $60{ }^{\circ} \mathrm{C}$ during 2 hours; (iv), 116 they are mixed with a $1 \mathrm{M} \mathrm{NaOH}$ solution and heated at $60{ }^{\circ} \mathrm{C}$ during 1 hour in the $\mathrm{SB}$, (33), (34) to 117 remove all proteins and lipids. After bacterial lysis and each of the five treatments with detergents, 118 magnetosomes are isolated from non-magnetic organic debris using a neodymium magnet. The 119 supernatant is then removed and replaced by a detergent. Uncoated magnetosome minerals labelled $\mathrm{N}$ 120 containing a low percentage of residual organic materials are thus obtained. They are autoclaved and 121 stored at $-80^{\circ} \mathrm{C}$.

Coated magnetosome minerals, N-PLL, N-CA, N-OA, and N-CMD. Coating procedures are carried out under sterile conditions, using a sterile flow hood. To prepare the different suspensions of coated magnetosome minerals, four different solutions are first prepared containing: i), $300 \mathrm{mg}$ of polyL-lysine, PLL, hydrobromide powder dissolved in $6 \mathrm{ml}$ of pyrogen-free water, ii), $105 \mathrm{mg}$ of citric acid, CA, monohydrate powder dissolved in $6 \mathrm{ml}$ of pyrogen-free water, iii), $800 \mathrm{mg}$ of oleic acid, OA, in 40 $\mathrm{ml}$ of pyrogen-free water, iv), $840 \mathrm{mg}$ of carboxy methyl dextran, CMD, powder dissolved in $12 \mathrm{ml}$ of pyrogen-free water. They are filtered with a polyether sulfone filter of $0.2 \mu \mathrm{m}$ and their $\mathrm{pH}$ values are adjusted at $10.5,6,11.5$ or 4.1 for the PLL, CA, OA and CMD solutions, respectively. $1.5 \mathrm{~mL}$ of a suspension of uncoated magnetosome minerals at $20 \mathrm{mg}$ of iron $/ \mathrm{ml}$ is then positioned against a 131 neodymium magnet of remanence $1.3 \mathrm{~T}$ during 5 minutes. The supernatant is removed and replaced by $1326 \mathrm{~mL}$ of a PLL solution at $50 \mathrm{mg} / \mathrm{ml}, 6 \mathrm{~mL}$ of a CA solution at $17.5 \mathrm{mg} / \mathrm{ml}, 7.5 \mathrm{~mL}$ of an OA solution 133 at $20 \mathrm{mg} / \mathrm{ml}$, or $6 \mathrm{~mL}$ of a CMD solution at $70 \mathrm{mg} / \mathrm{ml}$. The different mixtures are then sonicated in the $134 \mathrm{SB}$ during 5 hours at $37^{\circ} \mathrm{C}$ for $\mathrm{N}-\mathrm{PLL}$, in the $\mathrm{SB}$ during 5 hours at $90^{\circ} \mathrm{C}$ for $\mathrm{N}-\mathrm{CA}$, using a sonicating 135 finger at $10 \mathrm{~W}$ during $1 \mathrm{~h} 30$ for $\mathrm{N}-\mathrm{OA}$, or in the $\mathrm{SB}$ overnight at room temperature for N-CMD. The 136 protocols for obtaining stable nanoparticles with these different coating agents have been adapted from 
previously described coating conditions used with chemically synthesized iron oxide nanoparticles:

138 Babic \& al. (2008) for N-PLL (35), Kotsmar \& al. (2010) for N-CA (36), Jain \& al. (2005) and Yang \&

139 al. (2009) for N-AO (37,38) and Liu \& al. (2011) for N-CMD (39). Protocols resulting from these 140 articles have been modified in order to have a manufacturing process without harmful products. After 141 sonication, the different suspensions of coated magnetosome minerals are centrifuged at $13000 \mathrm{~g}$ during 14290 minutes, the supernatant is removed and replaced by pure water. A neodymium magnet is then 143 positioned against the tube containing the different suspensions of coated magnetosome minerals, the 144 supernatant is removed and replaced by pure water.

\section{Characterization of different nanoparticles suspensions}

Quantification of iron concentration. To verify total iron concentration of each nanoparticle suspension, nanoparticles are first mixed with a $12 \mathrm{~N}$ hydroxide chloride and hydrogen peroxide to produce $\mathrm{Fe}^{3+}$ ions complexed with 2 moles per liters of potassium thiocyanate. Iron concentration is then measured at $476 \mathrm{~nm}$ with a spectrophotometer (UviLine 9400 Secomam).

Transmission electron microscopy (TEM). To determine the morphology, size, dispersion of the different nanoparticles, $5 \mu \mathrm{L}$ at $100 \mu \mathrm{g} / \mathrm{ml}$ of each nanoparticle suspension mixed in water are deposited on top of a carbon-coated copper grid (300 mesh from Oxford instruments). They are dried at room temperature and examined using a JEOL JEM-2100 apparatus using a LaB6 gun operated at $200 \mathrm{kV}$. Nanoparticle size and size distribution are estimated by measuring nanoparticle diameters on 500 nanoparticles using the Image $\mathrm{J}$ software.

Nanoparticle stability in suspension. The colloidal stability of each nanoparticle suspension is evaluated using $1 \mathrm{mg}$ of a homogenized nanoparticle suspension mixed in $1 \mathrm{ml}$ of water and placed in a quartz cuvette. The variation of the absorption of nanoparticle suspensions with time is measured at 476 nm during 20 minutes using a UviLine 9400 Secoman spectrophotometer. The preparation was carried 
measurements are the sum of the measurements carried out during each day within 1 month on three

162 batches of nanoparticles (triplicates). The measurements are performed during 20 minutes after manual 163 shaking. Data are averages of three different measurements.

Zeta potential measurements. Electrokinetic potential or Zeta potential, related to nanoparticle surface charge, is measured at $25^{\circ} \mathrm{C}$ using a Zetasizer Nano ZS from Malvern Instruments for each type of nanoparticle dispersed in water, at a $\mathrm{pH}$, which is varied between 2 and 12 using a $\mathrm{NaOH}$ or $\mathrm{HCl}$ solution. Results are averages of three different measurements. powders containing the different nanoparticles using a Bucker Vertex 70 ATR Pike Germanium. Each sample spectrum has a $1 \mathrm{~cm}^{-1}$ resolution and is obtained for wavenumbers varied between 4000 and 400 $\mathrm{cm}^{-1}$. Scientific) is used to determine the carbon and nitrogen contents of each lyophilized nanoparticle suspension, containing $3 \mathrm{mg}$ of iron of the different nanoparticle suspensions. Data are averages of three measurements.

Limulus amebocyte lysate (LAL) assay used to estimate endotoxin concentrations in nanoparticle suspensions. This assay is carried out on each nanoparticle suspension to determine endotoxin concentrations, using a Pierce LAL Chromogenic Endotoxin Quantitation Kit (88282 ThermoScientific). $1 \mathrm{ml}$ of each suspension is washed with pyrogen-free water and heated at $70^{\circ} \mathrm{C}$ over 10 minutes to denature any residual protein that could interfere with the LAL assay. $25 \mu 1$ of each 181 suspension containing $10 \mu \mathrm{g}$ in iron are introduced in a 96-well and maintained at $37{ }^{\circ} \mathrm{C}$ during the experiment. $25 \mu 1$ of the LAL solution are added to initiate the reaction. After 10 minutes of reaction, 50

$183 \mu \mathrm{l}$ of the chromogenic substrate are added to the well during 6 minutes and the amount of endotoxins is 184 detected. Finally, $25 \mu 1$ of acetic acid are added to stop the reaction. The optical density of the obtained 
suspension is measured at $405 \mathrm{~nm}$ using a microplate reader. The endotoxin concentration is then estimated using the calibrating curve provided with the kit. To verify that the LAL test does not interfere with the nanoparticles, a recovery rate, defined as $\mathrm{C}_{\text {total }}\left(\mathrm{C}_{1}+\mathrm{C}_{2}\right)$ is measured, where $\mathrm{C}_{\text {total }}$ is the endotoxin concentration of the nanoparticle suspensions mixed with a known amount of endotoxin of $0.5 \mathrm{UE} / \mathrm{mL}, \mathrm{C}_{1}$ being the concentration of endotoxins in the different suspensions of nanoparticles and $\mathrm{C}_{2}=0.5 \mathrm{UE} / \mathrm{mL}$. The estimated recovery rate during the different steps is lower than $50 \%$, indicating that the nanoparticles did not interfere with LAL test. Data are averages of three measurements.

\section{Cell culture}

Mouse (GL-261) and Rat (RG2) glioblastoma cells GL-261 cells were purchased from NCIFrederick (Sample number: 0507812) and cultured in RPMI 1640 medium with L-glutamine (Hyclone) supplemented with $20 \%$ of Foetal Bovine Serum (Gibco) and 1\% with streptomycin-penicillin solution (10 units penicillin; $10 \mu \mathrm{g} / \mathrm{ml}$ of streptomycin from Hyclone), at $37^{\circ} \mathrm{C}$ in $5 \% \mathrm{CO}_{2}$. Rat glioblastoma cells (RG2) were purchased from ATCC (CRL-2433) and cultured in DMEM medium (Hyclone) supplemented with $10 \%$ of Foetal Bovine Serum (Gibco), $0.11 \mathrm{~g} / \mathrm{L}$ of sodium pyruvate (Hyclone), penicillin G sodium (50 units $/ \mathrm{ml}$ from Hyclone) and $50 \mu \mathrm{g} / \mathrm{ml}$ of streptomycin sulfate (Hyclone) at $37^{\circ} \mathrm{C}$ in $5 \% \mathrm{CO}_{2}$.

Mouse fibroblast cells, BALB/c 3 T3 clone 31 (3T3). 3 T3 cells were purchased from ATCC (CCL-163) and cultured in DMEM medium (Hyclone) supplemented with 5\% of Newborn Calf Serum (Hyclone), $4 \mathrm{mM}$ of L-glutamine, $0.5 \mathrm{~mL}$ of streptomycin-penicillin solution (10 units penicillin; $10 \mu \mathrm{g}$ $/ \mathrm{ml}$ of streptomycin from Hyclone), and $20 \mathrm{mM}$ of $1 \mathrm{M}$ HEPES (Hyclone), at $37^{\circ} \mathrm{C}$ in $5 \% \mathrm{CO}$. For all experiments, confluent cell monolayers are trypsinized with $0.25 \%$ Trypsine-EDTA (Gibco).

\section{In vitro cytotoxicity assay of the different nanoparticles.}


nanoparticles is determined using the NRU assay on healthy BALB/c 3T3 cell lines according to the

209 protocol described in the standard ISO 10993-5. This assay is based on the accumulation of the neutral 210 red dye in the lysosomes of viable cells. $1.10^{4}$ cells per well are seeded in a 96-well plate and incubated 211 overnight at $37^{\circ} \mathrm{C}$ in $5 \% \mathrm{CO}_{2}$. The following day, the culture medium is removed and replaced by 100 $212 \mu 1$ of complete medium with different nanoparticle and iron concentrations of $15.6,31.2,62.5,125,500$, 213 or $1000 \mu \mathrm{g} / \mathrm{ml}$; cells are incubated at $37^{\circ} \mathrm{C}$ in $5 \% \mathrm{CO} 2$ during 24 hours. Then, cells are washed once 214 with a solution containing $150 \mu \mathrm{l}$ of PBS with calcium and magnesium chloride. $100 \mu 1$ of a Neutral 215 Red solution at $50 \mu \mathrm{g} / \mathrm{ml}$ is added to the cells and incubated during 3 hours at $37^{\circ} \mathrm{C}$ in $5 \% \mathrm{CO}_{2}$. 216 Following exposure to $3 \mathrm{~T} 3$ cells, cells are washed again with $150 \mu 1$ of PBS and $150 \mu 1$ of Neutral Red 217 desorbing fixative (glacial acetic acid solution: ethanol: water ; 1\%: 50\%: 49\%) is added followed 218 gentle shaking for $10 \mathrm{~min}$ to complete dissolution. Absorbance at $540 \mathrm{~nm}$ is measured using a Multiskan 219 FC microplate reader. The percentage of cells inhibition (\% Inhibition), is calculated using the formula: $\%$ Inhibition $=\left(1-\left(\frac{\mathrm{DO}_{\text {sample }}}{\mathrm{DO}_{\text {control }}}\right)\right) \times 100$, where $\mathrm{DO}_{\text {sample }}$ is the absorbance of cells with nanoparticles and $\mathrm{DO}_{\text {control }}$ is the absorbance of cells only. These experiments are carried out in triplicate.

MTT assay. Cytotoxicity of different nanoparticles on GL-261 and RG2 cell lines is determined using the MTT (3-(4, 5-dimethylthiazol-2-yl)-2, 5-diphenyltetrazolium bromide) assay. 5.10 $0^{3}$ cells per well are seeded in a 96-well plate and incubated overnight at $37^{\circ} \mathrm{C}$ in $5 \% \mathrm{CO}_{2}$. The following day, the culture medium is removed and replaced by $100 \mu 1$ of complete medium with different nanoparticle and iron concentrations of $15.6,31.2,62.5,125,500$, or $1000 \mu \mathrm{g} / \mathrm{ml}$; cells are incubated at $37^{\circ} \mathrm{C}$ in $5 \% \mathrm{CO}_{2}$ during 72 hours. Then, cells are washed once with a solution containing PBS with calcium and magnesium chloride. $100 \mu \mathrm{l}$ of a MTT solution at $1 \mathrm{mg} / \mathrm{ml}$ is added to the cells and incubated during 2 hours at $37^{\circ} \mathrm{C}$ in $5 \% \mathrm{CO}_{2}$. The MTT solution is carefully removed and replaced by $100 \mu \mathrm{l}$ of an 230 isopropanol solution. The plates are mixed thoroughly to dissolve purple formazan crystals and 231 incubated at $37{ }^{\circ} \mathrm{C}$ during 4 hours to ensure that all crystals are dissolved. Then the optical density 
representing the viable cell number resulting from the solubilized purple formazan is estimated at 540

$233 \mathrm{~nm}$ using a Multiskan FC microplate reader. And the percentage of cells inhibition (\% Inhibition), is

234 calculated from the formula: \% Inhibition $=\left(1-\left(\frac{\mathrm{DO}_{\text {sample }}}{\mathrm{DO}_{\text {control }}}\right)\right) \times 100$, where $\mathrm{DO}_{\text {sample }}$ is the absorbance 235 of cells with nanoparticles and $\mathrm{DO}_{\text {control }}$ is the absorbance of cells only. These experiments are carried 236 out in triplicate. To get rid of the interference between the MTT assay and the nanoparticles, we 237 subtracted the value of the optical density of the assembly containing cells and nanoparticles to the 238 value of the optical density obtained after adding MTT to the assembly. The same protocol was 239 followed with Neutral Red.

240 In vitro nanoparticle antitumor and heating efficacies as well as nanoparticle cellular 241 internalization in the presence of the AMF.

242 Magnetic hyperthermia set-up. In an attempt to get close to in vivo treatment conditions, the magnetic 243 hyperthermia experimental set-up was not adiabatic. We used an induction system and a coil of $7 \mathrm{~cm}$ to 244 expose the mixture of cells and nanoparticles to an alternating magnetic field (AMF) of 34-47 mT and $245198 \mathrm{kHz}$.

Hyperthermia treatment with AMF. In vitro studies are carried out using $1 \mathrm{mg}$ in iron of the different nanoparticle suspensions brought into contact with GL-261 cells and exposed during 30 minutes to an 248 alternating magnetic field of $198 \mathrm{kHz}$ and strength of 34 to $47 \mathrm{mT}$. $2.510^{5} \mathrm{GL}-261$ cells are seeded in a $24935 \mathrm{~mm}$ Petri dish and incubated for 24 hours at $37^{\circ} \mathrm{C}$ in $5 \% \mathrm{CO}_{2}$. After 24 hours, the culture medium is 250 removed and replaced by $2 \mathrm{ml}$ of complete medium with or without $1 \mathrm{mg}$ (concentration $=0.5 \mathrm{mg} / \mathrm{mL}$ et 251 pas $1 \mathrm{mg} / \mathrm{mL}$ ?) of the different nanoparticles. Samples are then, or not for the control, exposed during 25230 minutes to either one of the following two magnetic treatments. In the first magnetic treatment, 253 temperature is maintained at $43^{\circ} \mathrm{C}-46^{\circ} \mathrm{C}$ by applying an alternating magnetic field of frequency 198 $254 \mathrm{kHz}$ and strength adjusted manually between 34 and $47 \mathrm{mT}$. In the second one, an alternating magnetic 
255 field of $198 \mathrm{kHz}$ and strength $34 \mathrm{mT}$ is applied. The temperature is measured by the infrared camera 256 (ThermoPro ${ }^{\mathrm{TM}}$ EasIR-2 Thermal Imager) and infrared images are analyzed by the provided analyzer 257 software.

The second magnetic treatment is used to measure the specific absorption rate (SAR), measured in Watt per gram of iron, of the different nanoparticles mixed with GL-261 cells. SAR is estimated

260 using the formula: $\mathrm{SAR}=\mathrm{C}_{\text {water }} \cdot\left(\frac{\delta \mathrm{T}}{\delta \mathrm{t}}\right) \cdot\left(\frac{1}{\mathrm{C}_{\text {iron }}}\right)$, where $\mathrm{C}_{\text {water }}=4.2 \mathrm{~J} /(\mathrm{g} \cdot \mathrm{K})$ is the specific heat capacity of 261 water, $\Delta \mathrm{T} / \delta \mathrm{t}$, measured in ${ }^{\circ} \mathrm{C} / \mathrm{s}$, is the initial slope of the temperature variation with time and $\mathrm{C}_{\mathrm{iron}}$, 262 measured in $\mathrm{g}$ of iron per $\mathrm{g}$ of water, is the iron concentration in the different nanoparticle suspensions. 263 The choice of these parameters seems accurate since heat capacities of culture medium and water are 264 similar, (ref), and nanoparticle concentrations do not change significantly when nanoparticles are mixed 265 in culture medium (vérifier). Data are averages over three measurements.

Flow cytometer measurements. Following these two magnetic treatments, cells are washed once with a solution containing PBS with calcium and magnesium, and incubated during 24h with $2 \mathrm{ml}$ of complete medium at $37^{\circ} \mathrm{C}$ in $5 \% \mathrm{CO}_{2}$. In order to harvest cells, the culture medium is removed and replaced by $500 \mu \mathrm{l}$ of Trypsin-EDTA. $2 \mathrm{ml}$ of complete medium are added to neutralize Trypsin-EDTA and to obtain a cell suspension whose cell viability is measured with a flow cytometer. Before and after 271 one magnetic treatment, the percentage of living cells is estimated. For that, $5 \mu \mathrm{L}$ of $20 \mathrm{mg} / \mathrm{ml} \mathrm{of}$ 272 propidium iodide (PI) is introduced in $500 \mu \mathrm{l}$ of a GL-261 tumor cell suspension mixed with the 273 different nanoparticles. A Flow cytometer (Beckton Dickinson FACS Calibur 3C, BD Biosciences) is 274 used to excite PI with an argon laser at $488 \mathrm{~nm}$ and to detect PI emission with a FL3-H detector. PI, 275 which only penetrates in inactivated cells, is used to estimate the percentage of inactivated cells. Twenty 276 thousand cells per sample were measured to determine the percentage of living cells.

Internalization of nanoparticles. Before and after one magnetic treatment, the quantity of iron 278 of nanoparticles internalized in GL-261 cells is also measured. GL-261 tumor cells are first washed 
279 twice with PBS to remove nanoparticles from cell surface and it is verified by optical microscope 280 observation that nanoparticle aggregates do not remain at the cell surface and that the quantity of iron 281 actually mainly corresponds to the quantity of iron internalized in cells, whether it corresponds to 282 crystallized or dissolved iron. $500 \mu \mathrm{l}$ of GL-261 tumor cells are collected for cell counting and $1 \mathrm{ml}$ of 283 each cell suspension is used to measure the quantity of iron contained per cell. For that, cell suspensions 284 are first centrifuged at $13000 \mathrm{~g}$ during 10 minutes. The supernatant is removed and the cell pellet 285 containing cells and nanoparticles is re-suspended with $250 \mu \mathrm{l}$ of $\mathrm{HCl}: \mathrm{HNO}_{3}$ (3:1) solution and 286 incubated overnight. This $\mathrm{HCl}: \mathrm{HNO}_{3}(3: 1)$ solution dissolves crystallized iron oxide into $\mathrm{Fe}^{2+}$ and $\mathrm{Fe}^{3+}$ 287 ions and denatures cell membranes. $50 \mu \mathrm{l}$ of each sample are mixed with $50 \mu \mathrm{l}$ of $\mathrm{HCl}(6 \mathrm{~N}), 50 \mu 1$ of $288 \mathrm{H}_{2} \mathrm{O}_{2}(20 \%)$ and $50 \mu \mathrm{l}$ of potassium thiocyanate $(2 \mathrm{M})$. This mixture induces the formation of a complex 289 between iron (III) and thiocyanate ions. Measurement of iron internalized in cells is estimated by 290 measuring the concentration of this complex by absorption at $476 \mathrm{~nm}$. Hyperthermia treatments and 291 internalization studies were carried out without washing cells following nanoparticle incubation in the 292 first case and with washing cells following nanoparticle incubation in the second case. In this way, we 293 could study nanoparticle toxicity towards cells as well as nanoparticle cellular internalization in the 294 presence of AMF. 
To produce a magnetosome suspension, which can be used as a medicinal product, four steps are

followed: i), MSR-1 magnetotactic bacteria are first cultivated, ii), pyrogenic magnetosomes chains are 299 then extracted from these bacteria, called MC, iii), MC are purified to yield a suspension of 300 magnetosome minerals, called $\mathrm{N}$, which only contains a small quantity of organic material coming from 301 these bacteria, iv), magnetosome minerals are then coated with PLL, CA, OA, and CMD to produce 302 four different coated magnetosome minerals, called N-PLL, N-CA, N-OA, and N-CMD, respectively.

\section{Characterization of samples containing uncoated magnetosome minerals extracted from whole} MSR-1 magnetotactic bacteria and purified

MSR-1 magnetotactic bacteria, which are used in this study to produce magnetosomes, are characterized using transmission electron microscopy (TEM). When $5 \mu 1$ of a suspension containing these bacteria are deposited on top of a carbon-thin-film-covered grid, dried and observed by TEM, Fig.Fig. 1(a) shows that each bacterium typically contains a long chain of 30 magnetosomes, (Faivre2008). ). Despite of better heating properties compared to their chemical counterparts, (20), (40), magnetosomes from MTB are not currently used as a medicinal product, most probably due to the presence of endotoxins, including lipopolysaccharides, which could contaminate magnetosome medicinal preparations. Since magnetosome formation results from the invagination of the bacterial membrane, (40), endotoxin concentration at magnetosome surface might be higher than the tolerated concentration.

In this study, $\mathrm{MC}$ are therefore extracted from magnetotactic bacteria with $\mathrm{NaOH}$ and then treated with a series of different detergents (SDS, Triton X100, phenol and chloroform) at a temperature of $60^{\circ} \mathrm{C}$ in the presence of sonication to remove most of the organic material, including endotoxins, coming from MSR-1 magnetotactic bacteria. Uncoated magnetosome minerals are thus obtained and characterized. 
When $2 \mu 1$ of a suspension of uncoated magnetosome minerals are deposited on top of a carbon grid and

321 observed by TEM, no remains of organic material remain visible (Fig.1(c)). These uncoated 322 magnetosome minerals aggregate strongly and have a mean size of $43 \mathrm{~nm}$ (Fig. 2(a)), which is larger 323 than that of $21 \mathrm{~nm}$, observed for IONP (Fig. 1(b)). Treatments involved in magnetosome extraction and 324 purification did not significantly modify magnetosome morphology and size, with reference to those 325 observed in whole magnetotactic bacteria. The FT-IR spectrum of a lyophilized suspension of uncoated 326 magnetosome minerals, presented in Figure 3(a), shows two dominant peaks attributed to iron oxide at $327609 \mathrm{~cm}^{-1}$ and $673 \mathrm{~cm}^{-1},(42)$. When they are contained inside magnetotactic bacteria, magnetosome iron 328 oxide composition consist of magnetite,(43). After extraction and purification, saturating isothermal 329 remanent magnetization (SIRM) measurements, carried out on uncoated magnetosome minerals, reveal a maghemite composition, (44). Additional peaks observed in FT-IR spectra at $1041 \mathrm{~cm}^{-1}, 2926 \mathrm{~cm}^{-1}$, and $3267 \mathrm{~cm}^{-1}$, (Fig.3(a)), are attributed to $\mathrm{PO}, \mathrm{C}-\mathrm{H}, \mathrm{NH}_{2}$ and $\mathrm{OH}$ vibrational modes, respectively. These signals are due to residual organic material remaining at the magnetosome mineral surface after purification. The quantity of this organic material is further estimated by CHNS measurements carried out on a homogenized lyophilisate of uncoated magnetosome minerals. These measurements reveal the presence of $2.39 \pm 0.04 \%$ of carbon residue coming from whole magnetotactic bacteria in $1 \mathrm{mg}$ of uncoated magnetosome minerals (Fig. 2(b)). Concerning the endotoxin concentration in the suspension of uncoated magnetosome minerals, it lies between 10 and $160 \mathrm{EU} / \mathrm{ml}$ per $\mathrm{mg}$ of iron as estimated by a LAL test. This indicates that uncoated magnetosome minerals are much less pyrogenic than suspensions of whole magnetotactic bacteria, characterized by endotoxin concentrations larger than $1.10^{5} \mathrm{EU} / \mathrm{ml}$ per $\mathrm{mg}$ of iron, and then suspensions containing $\mathrm{MC}$ extracted from magnetotactic bacteria by a unique $\mathrm{NaOH}$ treatment, which possess endotoxin concentrations lying between 2000 and $12000 \mathrm{EU} / \mathrm{ml}$ per mg of iron. However, uncoated magnetosome minerals tend to aggregate as revealed by TEM image shown in Figure 1(c), and by absorption measurements at $480 \mathrm{~nm}$ of a suspension containing $1 \mathrm{mg} / \mathrm{ml}$ in iron of uncoated magnetosome minerals. Their absorption signal decreases rapidly by $80 \%$ in 20 345 minutes (Fig. 2(c)). Moreover, the variation of the surface charges of these uncoated magnetosome 
minerals as a function of $\mathrm{pH}$ is shown in Fig. 2(e). It shows a zeta potential increase from $-15 \mathrm{mV}$ to 0

$347 \mathrm{mV}$ between $\mathrm{pH} 5$ and 6 followed by a zeta potential decrease from 0 to $-20 \mathrm{mV}$ between pH 6 and 7 .

348 Such a large variation in zeta potential, observed within a relatively narrow range of $\mathrm{pH}$, could be 349 explained by magnetosome aggregation, which is believed to be dependent on surface charge, (21). Zeta 350 potential with measurements of the surface charge make it possible to establish the degree of interaction 351 between nanoparticles, in our example a significant variation in the surface charge would indicate 352 nanoparticles more or less aggregated devoid largely of the layer of original biological material. For 353 medical applications, it is essential to use suspensions that are stable since aggregation can lead to 354 embolism in vivo, and can also prevent a thorough magnetosome administration and a uniform 355 magnetosome heat production.

\section{Characterization of suspensions containing coated magnetosome minerals}

Administration to an individual of a magnetosome suspension requires the use of a stable suspension. To achieve this aim, magnetosome minerals are coated with PLL, CA, OA, or CMD, chosen for their good solubility in water, biocompatibility and low toxicity, (35-39) minerals, N-PLL, N-CA, N-OA, N-CMD, respectively deposited on carbon grids for TEM observations (Figs. 1(d) to 1(k)) which reveal the presence of a coating material surrounding magnetosome mineral cores with average thicknesses between 4 and $6 \mathrm{~nm}$ for N-PLL, 2 and $5 \mathrm{~nm}$ for N-CA, 3 and $5 \mathrm{~nm}$ for

N-CMD and lower than $2 \mathrm{~nm}$ for N-OA. TEM images of Figures 1(d) to 1(k) show that N-PLL, N-CA, 366 presented elsewhere, (ref), and demonstrated for magnetosomes directly extracted from AMB-1 367 magnetotactic bacteria, (44). Chemically synthesized iron oxide nanoparticles are rarely reported to 368 organize in chains. When an organization in chains of such nanoparticles is described, (45), their

369 behavior contrasts with that observed with coated magnetosome minerals. Indeed, chemically 370 synthesized nanoparticles do not appear to have preferential alignments and are usually 
superparamagnetic. FT-IR spectra of lyophilized suspensions of N-PLL, N-CA, N-OA and N-CMD,

provide further support for the presence of the various coating agents at the magnetosome mineral surfaces. For N-PLL, peaks at $1546 \mathrm{~cm}^{-1}, 1651 \mathrm{~cm}^{-1}$ and $3266 \mathrm{~cm}^{-1}$ are attributed to the $\mathrm{NH}, \mathrm{C}=\mathrm{O}$ and

$\mathrm{NH}_{2}$ bonds of poly-L-lysine respectively (Fig. 3(c)). Concerning N-CA, the peaks at $1631 \mathrm{~cm}^{-1}$ and $3250 \mathrm{~cm}^{-1}$ are due to $\mathrm{C}=\mathrm{O}$ and $\mathrm{OH}$ bonds of citric acid (Fig. 3(d)). Regarding N-OA, the peaks at 1427 $\mathrm{cm}^{-1}, 1546 \mathrm{~cm}^{-1}$ and $3250 \mathrm{~cm}^{-1}$ are attributed to $\mathrm{C}-\mathrm{O}, \mathrm{C}=\mathrm{O}$ and $\mathrm{OH}$ bonds of oleic acid (Fig. 3(e)). Similarly, for N-CMD, the peaks at $1034 \mathrm{~cm}^{-1}$ and $3250 \mathrm{~cm}^{-1}$ arise from the $\mathrm{C}-\mathrm{O}$ and $\mathrm{OH}$ bonds of carboxy-methyl-dextran. CHNS measurements, carried out on lyophilized suspensions of N-PLL and NOA show a percentage of carbon of $4.91 \pm 0.09 \%$ and $8.16 \pm 0.02 \%$ respectively, which is higher than that of $2.39 \pm 0.04 \%$, which is estimated for uncoated magnetosome minerals (Fig. 2 (b)). This result suggests that in N-PLL and N-OA coating material is added to mostly uncoated magnetosome minerals.

By contrast, for N-CA and N-CMD, CHNS measurements reveal a percentage of carbon of $2.41 \pm$

$0.16 \%$ and $2.37 \pm 0.02 \%$, which is similar to that estimated for uncoated magnetosome minerals. In $\mathrm{N}$ -

$\mathrm{CA}$ and $\mathrm{N}-\mathrm{CMD}$, it is therefore possible that residual organic material at the surface of uncoated magnetosome minerals has been replaced by the coating material. The presence of coating in nanoparticles mixed in suspension can also be observed from zeta potential measurements, which indicate that N-CA, (35), N-OA, (46), and N-CMD, (38), are negatively charged at $\mathrm{pH} 7$, a behavior which could be due to the presence of carboxylic and hydroxyl functional groups at the surfaces of N-

CA, N-OA, or N-CMD (Figs. 2(e) and 2(f)), while N-PLL appear positively charged at $\mathrm{pH} 7$, a property that could come from the presence of a tertiary amine function ( $\mathrm{pKa}$ of PLL $=10.5$ ) at N-PLL surface 391 (Fig. 2(e)). By contrast to uncoated magnetosome minerals, all four coated magnetosome minerals 392 appear to be stable in suspension. Indeed, the absorption of homogenized suspensions containing 1 $\mathrm{mg} / \mathrm{ml}$ of N-PLL, N-CA, N-OA and N-CMD, measured at $480 \mathrm{~nm}$, decreases by less than $40 \%$ in 20 394 minutes (Figs. 2(c) and 2(d)). The magnitude of this absorption decrease is comparable to that observed 395 for stable chemically synthesized nanoparticles IONP. Coating therefore leads to well dispersed N-PLL, 
N-CA, N-OA and N-CMD, as shown in the TEM images presented in Figures. 1(e, g, i, k) and confers

stability to the four different coated magnetosome minerals suspensions in water. Therefore, administration of these suspensions to human, which usually requires less than 20 minutes, seems feasible. The biocompatibility of these nanoparticles is first demonstrated using an LAL assay, which shows that the endotoxin concentration of N-PLL, N-OA, N-CA, and N-CMD suspensions is 21-160 $401 \mathrm{EU} / \mathrm{ml}$ per $\mathrm{mg}$ of iron for N-PLL, 20-130 EU/ml per $\mathrm{mg}$ of iron for N-CA, 10-105 EU/ml per mg of iron for N-OA, 23-140 EU/ ml per mg of iron for N-CMD. These concentrations are lower than $160 \mathrm{EU} / \mathrm{ml}$ 403 per $\mathrm{mg}$ of iron, an endotoxin concentration comparable to that of $140 \mathrm{EU} / \mathrm{ml}$ per $\mathrm{mg}$ of iron, measured 404 for chemically synthesized nanoparticles, IONPs.

\section{Cytotoxicity of the different nanoparticles towards healthy $3 T 3$ cells in the absence of magnetic}

treatment

Their biocompatibility is further determined following ISO 10993 standards. Such standards are

followed since uncoated and coated magnetosome mineral are both considered as medical devices given that their dominant mode of action does not involve any immunological, pharmacological or metabolic

410 effect but only heat. Cytotoxicity of suspensions containing various concentrations of IONP, uncoated 411 and coated magnetosome minerals, i.e. between $16 \mu \mathrm{g} / \mathrm{mL}$ and $1 \mathrm{mg} / \mathrm{mL}$, is estimated on healthy $3 \mathrm{~T} 3$ 412 cells using a NRU assay according to ISO 10993-5 standard. ISO 10993-12 recommends using a 413 concentration of $6 \mathrm{~cm}^{2} / \mathrm{ml}$ for medical devices with a high surface to volume ratio such as nanoparticles, 414 corresponding to $22 \mu \mathrm{g} / \mathrm{ml}$ for magnetosomes, (47).Therefore the tested concentration range includes 415 concentrations that are above the concentration of $6 \mathrm{~cm}^{2} / \mathrm{ml}$ recommended by ISO 10993-12. 3T3 cell 416 viability is measured after cellular incubation in the presence of the different nanoparticles during 24 417 hours. Figure 4(a) shows the percentage of $3 \mathrm{~T} 3$ cell inhibition as a function of nanoparticle 418 concentration, measured in $\mathrm{mg}$ of iron per $\mathrm{ml}$. When $3 \mathrm{~T} 3$ cells are brought into contact with IONP, N, 419 N-PLL, N-CA, N-OA and N-CMD, Figure 4(a) shows that the average percentage of cell inhibition 420 remains below $\sim 30 \%$, suggesting that the different nanoparticles are not cytotoxic below $1 \mathrm{mg}$ per $\mathrm{ml}$ 
according to the criteria of ISO 10993-5 standard. These experiments also indicate that inhibitory

concentrations leading to $50 \%$ cell inhibition, $\mathrm{IC}_{50}$, of the different nanoparticles are high and larger

423 than $1 \mathrm{mg}$ per $\mathrm{mL}$, indicating that these different nanoparticles are not cytotoxic towards healthy $3 \mathrm{~T} 3$

424 cells at these tested nanoparticle concentrations.

Cytotoxicity of the different nanoparticles towards glioblastoma GL-261 and RG-2 cells in the

absence of magnetic treatment

Cytotoxicity of suspensions containing IONP, uncoated and coated magnetosome minerals, is

further evaluated on glioblastoma GL-261 and RG2 cells using a MTT assay. Percentage of cell inhibition is estimated as a function of the different nanoparticle concentrations, varied between $15.6 \mu \mathrm{g}$

per $\mathrm{mL}$ and $1 \mathrm{mg}$ per $\mathrm{mL}$, after nanoparticle incubation during 24 hours with GL-261 (Figure 4(b)) or

RG2 (Figure 4(d)) cells. Uncoated iron oxide particles display low cytotoxicity towards 3T3, GL-261

and RG2 cells, with a percentage of cell inhibition remaining below $20 \%$ for all tested concentrations in

Figures 4(a), 4(b) and 4(d). As observed with IONP, N-PLL and N-CA reach a larger than 30\%

434 percentage of cell inhibition at $1 \mathrm{mg} / \mathrm{mL}$ and appear as observed with IONP to be more cytotoxic 435 towards GL-261 and RG2 cells than towards 3T3 cells (Figures 4(a), 4(b) and 4(d)). By contrast, 436 Figures 4(a), 4(b), and 4(d), show that N-OA are less cytotoxic towards GL-261 and RG2 cells than 437 towards 3 T3 cells. N-CMD display a rather unusual behavior with significant cytotoxicity towards 3T3 438 and RG2 cells (Figure 4(a) and 4(d)) and low cytotoxicity towards GL-261 cells (Figure 4(b)). IC50 439 values on GL-261 and RG2 cells, respectively of 269 and $355 \mu \mathrm{g} / \mathrm{ml}$ for N-PLL, 606 and $733 \mu \mathrm{g} / \mathrm{ml}$ 440 for $\mathrm{N}-\mathrm{CA}$, larger than $1 \mathrm{mg} / \mathrm{ml}$ and $919 \mu \mathrm{g} / \mathrm{ml}$ for $\mathrm{N}-\mathrm{CMD}$, and larger than $1 \mathrm{mg} / \mathrm{ml}$ for uncoated 441 magnetosomes, N-OA and IONP. In the absence of AMF application, optimal coating materials, which 442 may correspond to those leading to the largest cytotoxicity towards tumor cells and to the lowest 443 cytotoxicity towards healthy cells, may therefore be poly-L-lysine and citric acid. 
measured as a function of nanoparticle concentration, varied between $15.6 \mu \mathrm{g} / \mathrm{ml}$ and $1 \mathrm{mg} / \mathrm{ml}$, on GL-

261 (Figure 4(c)) and RG2 (Figure 4(e)) cells. Compared with 24 hours, the cytotoxicity is enhanced at

72 hours, leading to IC50 values, on GL-261 and RG2 cells, respectively larger than $1 \mathrm{mg} / \mathrm{ml}$ for N,

653 and $672 \mu \mathrm{g} / \mathrm{ml}$ for N-CMD, 271 and $433 \mu \mathrm{g} / \mathrm{ml}$ for $\mathrm{N}-\mathrm{CA}, 224 \mu \mathrm{g} / \mathrm{ml}$, and more than $1 \mathrm{mg} / \mathrm{ml}$ for IONP, 271 and $303 \mu \mathrm{g} / \mathrm{ml}$ for N-OA, and 6 and $197 \mu \mathrm{g} / \mathrm{ml}$ for N-PLL, respectively. IC 50 values are lower towards GL-261 cells than towards RG2 cells. Given that cytotoxicity towards tumor cells is 451 increased with incubation time, magnetic hyperthermia treatment efficacy may not decrease when 452 nanoparticles stay in the tumor.

Cytotoxicity of the various coated magnetosome minerals on GL-261 cells without AMF is due

to the coating since uncoated magnetosome minerals are characterized by an absence of cytotoxicity. It could be explained on the one hand by cytotoxic properties of the coating agents surrounding the magnetosome minerals (Suppl. Fig. 1 (a)) and on the other hand by variations in dispersion properties of the magnetosome minerals, as a function of their coatings, (23). Compared with commonly used cytotoxic cancer drugs characterized by $\mathrm{IC}_{50}$ values of $16.3 \mathrm{ng} / \mathrm{ml}$ for doxorubicin, (48), $4.1 \mu \mathrm{g} / \mathrm{ml}$ for tamoxifen, (48), 22 to $56 \mathrm{ng} / \mathrm{ml}$ for cisplatin, (49), and 96 to $120 \mathrm{ng} / \mathrm{ml}$ for carboplatin, (49), N-OA, N-

$460 \mathrm{CA}, \mathrm{N}-\mathrm{CMD}$, and N-PLL, possess much higher $\mathrm{IC}_{50}$ values. By contrast to conventional cytotoxic 461 cancer drugs, the main mode of action involved in tumor cell destruction using magnetic hyperthermia 462 with N-OA, N-CA, N-CMD, and N-PLL, thus does not come from their cytotoxicity, which would 463 require much lower $\mathrm{IC}_{50}$ values. Instead it comes from heat generated by AMF application.

Cell destruction, internalization, heating properties of the different nanoparticles in the presence of glioma GL-261 cells under alternative magnetic field application.

To measure the specific absorption rate (SAR) of IONP, uncoated and coated magnetosome minerals, $1 \mathrm{mg} / \mathrm{mL}$ in iron of these different nanoparticles is brought into contact with GL-261 cells 
$\mathrm{kHz}$ and average field strength of $34 \mathrm{mT}$. The variation with time of the average spatial temperature distribution over the whole Petri dish containing the cells mixed with the various nanoparticles is 471 presented in Figure 5(a). From the initial slopes of the plots of Figure 5(a), $0.018{ }^{\circ} \mathrm{C} / \mathrm{sec} .<\Delta \mathrm{T} / \delta \mathrm{t}<$ $0.047^{\circ} \mathrm{C} / \mathrm{sec}$., average SAR are estimated as $\sim 96 \mathrm{~W} / \mathrm{gFe}, \sim 73 \mathrm{~W} / \mathrm{gFe}, \sim 89 \mathrm{~W} / \mathrm{gFe}, \sim 141 \mathrm{~W} / \mathrm{gFe}, \sim$ $473100 \mathrm{~W} / \mathrm{gFe}, \sim 196 \mathrm{~W} / \mathrm{gFe}$ for N, IONP, N-PLL, N-CA, N-OA, and N-CMD, respectively (Table 1). 474 After 30 minutes of application of the alternating magnetic field, the maximum temperatures reached are measured as $39.4{ }^{\circ} \mathrm{C}, 35.0^{\circ} \mathrm{C}, 33.7^{\circ} \mathrm{C}, 41.8^{\circ} \mathrm{C}, 42.3{ }^{\circ} \mathrm{C}$ and $50.8^{\circ} \mathrm{C}$ for N, N-PLL, N-CA, N-OA, and N-CMD, respectively. In petri dishes, N-CMD, N-CA and N-OA lead to higher SAR values and maximum temperatures as well as to a more homogenous temperature distribution, where the latter may be defined as the temperature distribution that yields the largest percentage of heated area at $43-46{ }^{\circ} \mathrm{C}$ (table 2), a range of temperature that is reported to produce antitumor efficacy in hyperthermia treatment, (ref montrant que 1'hyperthermie a lieu pour des temperatures de chauffage supérieures à 43$46{ }^{\circ} \mathrm{C}$ ), compared with uncoated magnetosomes. The opposite behavior is observed for N-PLL having smaller SAR values and yielding smaller maximum temperatures and less homogenous temperature distribution than uncoated magnetosomes (Fig. 5(b)). This difference in behavior may be explained by 484 different thicknesses and properties of the coatings. Indeed, as observed in the TEM image of Fig. 1(e), 485 the largest coating thickness of $6.4 \mathrm{~nm}$ and possible changes in magnetosome morphology and chain 486 length, observed in N-PLL, leads to the lowest heating rates. Assuming that Brown relaxation is 487 occurring within these large nanoparticles as previously reported, (ref à trouver), the presence of such 488 thick coating could decrease N-PLL rotation motions or friction with the viscous surrounding, hence 489 minimizing the amount of heat produced. By contrast, magnetosome minerals with a thin coating seem 490 to heat more, possibly due to better thermal conductivity. Optimal coating thickness, leading to 491 enhanced heat production, appear to lie between 2 and $4.5 \mathrm{~nm}$ as is the case for N-CA, N-OA and N$492 \mathrm{CMD}$ and is close to the coating thickness of $\sim 6 \mathrm{~nm}$ of magnetosomes before purification, (ref à 493 rajouter). As a whole, N-PLL, N-CA, N-OA, and N-CMD, all lead to higher SAR values and equivalent 
or better heat distribution than IONP, suggesting that they all possess promising heating properties to carry out magnetic hyperthermia.

Next, we examine how efficiently N, IONP, N-CA, N-PLL, N-CMD, and N-OA can reach in vitro temperatures of $43-46^{\circ} \mathrm{C}$, which are typical temperatures desired for magnetic hyperthermia, (10: faux). For that, $1 \mathrm{mg}$ of the different nanoparticles is brought into contact with GL-261 cells during 24 hours and then exposed, or not for the control, to a heat treatment at $43-46^{\circ} \mathrm{C}$ during 30 minutes. Heat is maintained at these temperatures by applying an alternating magnetic field of frequency $198 \mathrm{kHz}$ and average strength of 34-47 mT. While for N-CA, N-OA, and N-CMD, a magnetic field strength of 33 to $40 \mathrm{mT}$ is needed to reach an average temperature in the Petri dish of $45^{\circ} \mathrm{C}$ after 30 minutes of treatment, leading to a more homogenous temperature distribution (Table 2) than for N and IONP (Figure 6(b)), a different behavior is observed for N-PLL that require the application of a higher magnetic field of 47 $\mathrm{mT}$ to reach an average temperature of $42{ }^{\circ} \mathrm{C}$ after 30 minutes of treatment and yield a less homogenous temperature distribution (Table 2) than for uncoated magnetosomes and IONP (Fig. 6(b)).

We now turn to a comparison between in vitro antitumor efficacy against GL-261 tumors of NCA, N-PLL, N-CMD, and N-OA, with that of uncoated magnetosomes and IONP. As shown in Figure 6(a), for all nanoparticles studied, the percentage of GL-261 living cells decreases in the presence of heat treatment at $43-46^{\circ} \mathrm{C}$. While for N-OA and N-CMD, GL-261 cell destruction appears to be the 511 most efficient, leading to a decrease in the percentage of living cells of $30-40 \pm 2 \%$ following heat 512 treatment, close to that of $53 \% \pm 2.2 \%$ observed with IONP, such decrease is only $10-16 \pm 2 \%$ for N513 PLL, N-CA and uncoated magnetosomes, lower than for IONP. For magnetic hyperthermia, it is 514 desirable to use nanoparticles that can induce cell destruction at low magnetic field strength to prevent 515 eddy currents. Therefore, N-OA and N-CMD seem to be the most efficient nanoparticles since their 516 relatively high percentage of cell destruction of $30-40 \pm 2 \%$ is correlated with relatively high 517 temperatures of $52-53{ }^{\circ} \mathrm{C}$ reached during 30 minutes of application of a magnetic field of relatively low 518 strength of 33-40 mT (Fig. 6(a)). Although IONP yield a relatively high percentage of cell destruction of 
reach requires the application of an alternating magnetic field of high strength of $47 \mathrm{mT}$ during 30

521 minutes (Fig. 6(b), which may produce Eddy currents resulting in global warming of the whole 522 organism, (Ref. : «Effects of size distribution on hysteresis losses of magnetic nanoparticles for 523 hyperthermia ",Rudolf Hergt, Silvio Dutz and Michael Roder (2008)). N-PLL and uncoated 524 magnetosomes appear to be the less promising nanoparticles since they induce the smallest percentages 525 of cell destruction of $16 \% \pm 2.3 \%$, obtained at relatively low temperatures of $42-48{ }^{\circ} \mathrm{C}$ by applying 526 magnetic fields of high strength of $47 \mathrm{mT}$ (Fig. 6(b)).

To examine whether in vitro antitumor efficacy is due to cellular internalization of the different nanoparticles, N-PLL, N-OA, N-CA, N-CMD, uncoated magnetosomes, and IONP, are exposed to the same heat treatment as above at $43-46{ }^{\circ} \mathrm{C}$. The different nanoparticles are removed from the cell surface by washing and it is verified by optical microscopy that nanoparticle aggregates do not remain at the 531 cell surface, so that the quantity of internalized nanoparticles, whether composed of crystallized or 532 dissolved iron, can be measured. As shown in Figure 7, after heat treatment, the amount of internalized 533 iron either increases from 1 to 4 pg per cell for N-PLL, from 2 to 18 pg per cell for N-CA, or remains 534 relatively unchanged at 0.5 to $4 \mathrm{pg}$ per cell for uncoated magnetosome minerals, N-OA, N-CMD and 535 IONP. High cellular internalization of N-CA in the presence of the heat treatment at $54{ }^{\circ} \mathrm{C}($ Figure $6(\mathrm{~b}))$ 536 may possibly be explained by N-CA high affinity for cellular membrane, as it is the case for 537 superparamagnetic nanoparticles coated with citric acid,(50). In the literature, anionic maghemite 538 nanoparticles have indeed been shown to have a high affinity for cellular membrane mainly due to 539 electrostatic interactions, (51). These behaviors may also take place with N-CA and promote their 540 cellular internalization.

541 On the one hand, N-CA that are prone to the highest level of internalization, produce a small 542 decrease in the percentage of GL-261 living cells of only $10 \% \pm 2.8 \%$ following heat treatment at $54{ }^{\circ} \mathrm{C}$, 
which may be due to the relatively limited cytotoxicity of citric acid ( $\left.\mathrm{IC}_{50} \sim 606 \mu \mathrm{g} / \mathrm{ml}\right)$, (50). This

544 hypothesis is further supported by analyzing the behavior of MC, which internalize and lead to

545 enhanced cytotoxicity following magnetic field application (Suppl. Figs. 1(a) and 1(b)). In this case, 546 cytotoxicity may arise from bacterial residues that enter inside cells following magnetic field 547 application. On the other hand, nanoparticles that appear to yield most efficient cell destruction, i.e. N$548 \mathrm{OA}$ and N-CMD with percentages of cell destruction of $43 \% \pm 2.9 \%$ and $30 \% \pm 2.0 \%$ respectively, do 549 not internalize much in cells, suggesting that internalization may not be the main factor responsible for 550 nanoparticle cytotoxicity. Instead, in vitro antitumor efficacy following alternating magnetic field 551 application may be due to aggregation of nanoparticles at the cell surface, to homogenous heating, 552 mechanic chocks between nanoparticles and cell membranes, or to extracellular hyperthermia, (52), 553 which could result in cell lysis. Chemical nanoparticles coated with OA have already been used to 554 induce toxicity in vitro under the application of an alternating magnetic field, (53), reinforcing the idea 555 that N-OA are-suitable for the magnetic hyperthermia treatment of tumors.

556 Coated magnetosome minerals also appear promising for magnetic hyperthermia, since N-PLL have 557 been shown to efficiently destroy both subcutaneous GL-261 and intracranial U-87 glioblastoma tumors 558 under AMF applications, as presented in details elsewhere, (43), (54).

\section{CONCLUSIONS}

560 In this study, we describe a process for purifying iron oxide nanoparticles extracted from 561 magnetotactic bacteria and removing most of the organic material, including endotoxins. The 562 nanoparticles are then stabilized with four different biodegradable and biocompatible coating agents.

563 These coated magnetosome minerals are characterized by a mineral crystallized core composed of 564 maghemite, which is surrounded by a layer of coating agent and are arranged in chains of coated 565 particles. Sedimentation and electro kinetic potential measurements reveal that they have good colloidal 566 stability at physiological $\mathrm{pH} 7.4$, which is a good criterion for injecting nanoparticles into tumor. 
Moreover, their endotoxin concentrations are below $160 \mathrm{EU} / \mathrm{ml}$ per $\mathrm{mg}$ and comparable to that of

chemically synthesized nanoparticles IONP. Cytotoxicity assays reveal that the percentage of healthy

3 T3 cell inhibition by N-PLL, N-CA, N-OA, and N-CMD at concentrations varied between $16 \mu \mathrm{g} / \mathrm{ml}$

and $1 \mathrm{mg} / \mathrm{ml}$ is lower than $30 \%$ indicating that, according to ISO 10993-5 standard, these nanoparticles

are not toxic. The SAR, measured when these nanoparticles are brought into contact with GL-261 cells and exposed during 30 minutes to an alternating magnetic field of $198 \mathrm{kHz}$ and strength $34 \mathrm{mT}$, lie between 89 and $196 \mathrm{~W} / \mathrm{gFe}$, larger than the SAR of $73 \mathrm{~W} / \mathrm{gFe}$, measured for chemically synthesized nanoparticles IONP, currently used to carry out magnetic hyperthermia treatment of tumors. In vitro anti-tumor efficacy of N-PLL, N-CA, N-OA, and N-CMD is also examined by bringing them into contact with GL-261 cells and by heating them to $43-46^{\circ} \mathrm{C}$ under application of an alternating magnetic field of $198 \mathrm{kHz}$ and 34-47 mT. Decrease in the percentage of living GL-261 cells following magnetic heat treatment is the largest for N-CMD and N-OA and the lowest for N-CA and N-PLL. Interestingly, N-CA internalize efficiently in GL-261 cells following magnetic heat treatment, while the opposite behavior is observed for N-CMD and N-OA. Therefore, efficient GL-261 tumor cell destruction does

581 not seem to be correlated with a high level of nanoparticle internalization, but instead with high SAR 582 values of $\sim 100-196 \mathrm{~W} / \mathrm{gFe}$ and with homogeneous heating at the scale of a Petri dish, measured for N583 CMD and N-OA. Although IONP yield a significant percentage of cell inhibition in the presence of the 584 AMF, this is achieved by using an AMF of high strength (47 mT), which should be avoided in humans, 585 since it can lead to Eddy currents and global warming of the organism. These results indicate that coated 586 magnetosome minerals are good candidates to carry out the magnetic hyperthermia treatment of tumors. SAR values and in vivo biodistribution should both be optimized to produce the most efficient magnetic 588 hyperthermia.

\section{ACKNOWLEDGMENT:}

590 We would like to thank the Eurostars program (Nanoneck-2, E9309), subvention AIR from the region of 591 Paris (A1401025Q) as well as the ANRT (CIFRE 2014/0359). Chalani Mandawala is a PhD student 
592 (CIFRE 2014/0359), working both at Nanobacterie and at the Muséum National d'Histoire Naturelle.

593 Chalani Mandawala carried out the experiments and Edouard Alphandéry directed the research 594 described in this article.

595 


\section{REFERENCES}

1. Gupta AK, Gupta M. Synthesis and surface engineering of iron oxide nanoparticles for biomedical applications. Biomaterials. juin 2005;26(18):3995- 4021.

2. Giakisikli G, Anthemidis AN. Magnetic materials as sorbents for metal/metalloid preconcentration and/or separation. A review. Analytica Chimica Acta. juill 2013;789:1-16.

3. Pankhurst QA, Connolly J, Jones SK, Dobson J. Applications of magnetic nanoparticles in biomedicine. Journal of Physics D: Applied Physics. 7 juill 2003;36(13):R167-81.

4. Berry, Catherine C, Curtis, Adam S.G. Functionalisation of magnetic nanoparticles for applications in biomedicine. J Phys D: Appl Phys. 2003;36:R198-R206.

5. Jordan A, Scholz R, Maier-Hauff K, van Landeghem FKH, Waldoefner N, Teichgraeber U, et al. The effect of thermotherapy using magnetic nanoparticles on rat malignant glioma. Journal of Neuro-Oncology. mai 2006;78(1):7- 14.

6. Zhao Q, Wang L, Cheng R, Mao L, Arnold RD, Howerth EW, et al. Magnetic Nanoparticle-Based Hyperthermia for Head \&amp; Neck Cancer in Mouse Models. Theranostics. 2012;2(1):113- 21.

7. Thiesen B, Jordan A. Clinical applications of magnetic nanoparticles for hyperthermia. International Journal of Hyperthermia. janv 2008;24(6):467- 74.

8. Silva AC, Oliveira TR, J. B. Mamani, Malheiros SMF, Malavolta L, Pavon LF, et al. Application of hyperthermia induced by superparamagnetic iron oxide nanoparticles in glioma treatment. International Journal of Nanomedicine. mars 2011;591.

9. Fine HA, Dear KB, Loeffler JS, Black PM, Canellos GP. Meta-analysis of radiation therapy with and without adjuvant chemotherapy for malignant gliomas in adults. CANCER-PHILADELPHIA-. 1993;71:2585-2585.

10. Branquinho LC, Carrião MS, Costa AS, Zufelato N, Sousa MH, Miotto R, et al. Effect of magnetic dipolar interactions on nanoparticle heating efficiency: Implications for cancer hyperthermia. Scientific Reports [Internet]. 7 oct 2013 [cité 1 juill 2016];3. Disponible sur: http://www.nature.com/articles/srep02887

11. Johannsen M, Gneveckow U, Eckelt L, Feussner A, WaldÖFner N, Scholz R, et al. Clinical hyperthermia of prostate cancer using magnetic nanoparticles: Presentation of a new interstitial technique. International Journal of Hyperthermia. nov 2005;21(7):637- 47.

12. Laurent S, Dutz S, Häfeli UO, Mahmoudi M. Magnetic fluid hyperthermia: Focus on superparamagnetic iron oxide nanoparticles. Advances in Colloid and Interface Science. août $2011 ; 166(1-2): 8-23$.

13. Frankel RB. The discovery of magnetotactic/magnetosensitive bacteria. Chinese Journal of Oceanology and Limnology. 2009;27(1):1-2.

14. Blakemore, Richard. Magnetotactic bacteria. Annual Revew of Microbiology. 1982;36:217- 38.

15. Frankel RB, Bazylinski DA. Magnetotaxis: Microbial. eLS. 2002;1 - 7. 
16. Lin W, Bazylinski DA, Xiao T, Wu L-F, Pan Y. Life with compass: diversity and biogeography of magnetotactic bacteria: Magnetotactic bacterial diversity and biogeography. Environmental Microbiology. sept 2014;16(9):2646- 58.

17. Bazylinski DA, Frankel RB, Heywood BR, Mann S, King JW, Donaghay PL, et al. Controlled Biomineralization of Magnetite (Fe (inf3) $\mathrm{O}$ (inf4)) and Greigite (Fe (inf3) $\mathrm{S}$ (inf4)) in a Magnetotactic Bacterium. Applied and Environmental Microbiology. 1995;61(9):3232-3239.

18. Schüler D. Genetics and cell biology of magnetosome formation in magnetotactic bacteria. FEMS Microbiology Reviews. juill 2008;32(4):654- 72.

19. Schüler D. Formation of magnetosomes in magnetotactic bacteria. Journal of molecular microbiology and biotechnology. 1999;1(1):79-86.

20. Alphandéry E, Faure S, Seksek O, Guyot F, Chebbi I. Chains of Magnetosomes Extracted from AMB-1 Magnetotactic Bacteria for Application in Alternative Magnetic Field Cancer Therapy. ACS Nano. 23 août 2011;5(8):6279-96.

21. Xiang L, Wei J, Jianbo S, Guili W, Feng G, Ying L. Purified and sterilized magnetosomes from Magnetospirillum gryphiswaldense MSR-1 were not toxic to mouse fibroblasts in vitro. Letters in Applied Microbiology. juill 2007;45(1):75-81.

22. Wang X, Wei F, Liu A, Wang L, Wang J-C, Ren L, et al. Cancer stem cell labeling using poly(1lysine)-modified iron oxide nanoparticles. Biomaterials. mai 2012;33(14):3719-32.

23. Răcuciu M, Creangă DE, Airinei A. Citric-acid-coated magnetite nanoparticles for biological applications. The European Physical Journal E. oct 2006;21(2):117- 21.

24. Bloemen M, Brullot W, Luong TT, Geukens N, Gils A, Verbiest T. Improved functionalization of oleic acid-coated iron oxide nanoparticles for biomedical applications. Journal of Nanoparticle Research [Internet]. sept 2012 [cité 30 juin 2016];14(9). Disponible sur: http://link.springer.com/10.1007/s11051-012-1100-5

25. Ghosh R, Pradhan L, Devi YP, Meena SS, Tewari R, Kumar A, et al. Induction heating studies of Fe3O4 magnetic nanoparticles capped with oleic acid and polyethylene glycol for hyperthermia. Journal of Materials Chemistry. 2011;21(35):13388- 98.

26. Barrera C, Herrera A, Zayas Y, Rinaldi C. Surface modification of magnetite nanoparticles for biomedical applications. Journal of Magnetism and Magnetic Materials. mai 2009;321(10):1397- 9.

27. Grüttner C, Müller K, Teller J, Westphal F, Foreman A, Ivkov R. Synthesis and antibody conjugation of magnetic nanoparticles with improved specific power absorption rates for alternating magnetic field cancer therapy. Journal of Magnetism and Magnetic Materials. avr 2007;311(1):181- 6 .

28. Schultheiss D, Schüler D. Development of a genetic system for Magnetospirillum gryphiswaldense. Archives of microbiology. 2003;179(2):89-94.

29. Zhang Y, Zhang X, Jiang W, Li Y, Li J. Semicontinuous Culture of Magnetospirillum gryphiswaldense MSR-1 Cells in an Autofermentor by Nutrient-Balanced and Isosmotic Feeding Strategies. Applied and Environmental Microbiology. 1 sept 2011;77(17):5851- 6. 
30. Philipse AP, Maas D. Magnetic Colloids from Magnetotactic Bacteria: Chain Formation and Colloidal Stability. Langmuir. déc 2002;18(25):9977- 84.

672

31. Xie J, Liu X, Liu W, Qiu G. Extraction of magnetosome from Acidthiobacillus ferrooxidans. Biomagnetism. 2005;1(3):36-38.

32. Grunberg K, Muller E-C, Otto A, Reszka R, Linder D, Kube M, et al. Biochemical and Proteomic Analysis of the Magnetosome Membrane in Magnetospirillum gryphiswaldense. Applied and Environmental Microbiology. 1 févr 2004;70(2):1040- 50.

33. Magalhães PO, Lopes AM, Mazzola PG, Rangel-Yagui C, Penna TC, Pessoa Jr A. Methods of endotoxin removal from biological preparations: a review. J Pharm Pharm Sci. 2007;10(3):388-404.

34. Babic M, Horák D, Trchová M, Jendelová P, Glogarová K, Lesnỳ P, et al. Poly (L-lysine)-modified iron oxide nanoparticles for stem cell labeling. Bioconjugate chemistry. 2008;19(3):740-750.

35. Kotsmar C, Yoon KY, Yu H, Ryoo SY, Barth J, Shao S, et al. Stable Citrate-Coated Iron Oxide Superparamagnetic Nanoclusters at High Salinity. Ind Eng Chem Res. 15 déc 2010;49(24):12435- 43.

36. Jain TK, Morales MA, Sahoo SK, Leslie-Pelecky DL, Labhasetwar V. Iron Oxide Nanoparticles for Sustained Delivery of Anticancer Agents. Molecular Pharmaceutics. juin 2005;2(3):194- 205.

37. Yang K, Peng H, Wen Y, Li N. Re-examination of characteristic FTIR spectrum of secondary layer in bilayer oleic acid-coated $\mathrm{Fe} 3 \mathrm{O} 4$ nanoparticles. Applied Surface Science. mars 2010;256(10):3093- 7 .

38. Liu G, Hong RY, Guo L, Li YG, Li HZ. Preparation, characterization and MRI application of carboxymethyl dextran coated magnetic nanoparticles. Applied Surface Science. mai 2011;257(15):6711- 7 .

39. Bazylinski DA, Frankel RB. Magnetosome formation in prokaryotes. Nature Reviews Microbiology. mars 2004;2(3):217-30.

40. Liu R, Liu J, Tong J, Tang T, Kong W-C, Wang X, et al. Heating effect and biocompatibility of bacterial magnetosomes as potential materials used in magnetic fluid hyperthermia. Progress in Natural Science: Materials International. févr 2012;22(1):31-9.

41. Predoi D, Andronescu E, Radu M, Munteanu MC, Dinischiotu A. Synthesis and characterization of biocompatible maghemite nanoparticles. Digest J Nanom Biostr. 2010;5:779-786.

42. Özdemir Ö, Dunlop DJ. The effect of oxidation on the Verwey transition in magnetite. Geophysical Research Letters. 1993;20(16):1671- 4.

43. Le Fèvre R, Durand-Dubief M, Chebbi I, Mandawala C, Lagroix F, Valet J-P, Maake C, Guyot F, Alphandéry E, Enhanced antitumor efficacy of biocompatible magnetosomes compared with chemically synthesized nanoparticles for the magnetic hyperthermia treatment of murine GL-261 glioblastoma.Manuscript in preparation.[When N-PLL and IONP were administered intratumorally to mice bearing GL-261 tumors and were then exposed 11 to 15 times to an alternating magnetic field of $198 \mathrm{kHz}$ and $25 \mathrm{mT}$ for 30 minutes, it led to $50 \%$ and $20 \%$ of mice fully cured with N-PLL and IONP, respectively.]. 
44. Alphandéry E, Ding Y, Ngo AT, Wang ZL, Wu LF, Pileni MP. Assemblies of Aligned Magnetotactic Bacteria and Extracted Magnetosomes: What Is the Main Factor Responsible for the Magnetic Anisotropy? ACS Nano. 23 juin 2009;3(6):1539- 47.

45. Abbas M, Islam MN, Rao BP, Abdel-Hamed MO, Kim C. Facile one-pot chemical approach for synthesis of monodisperse chain-like superparamagnetic maghemite $(\gamma$-Fe2O3) nanoparticles. Journal of Industrial and Engineering Chemistry. nov 2015;31:43- 6.

46. Chen ZP, Zhang Y, Zhang S, Xia JG, Liu JW, Xu K, et al. Preparation and characterization of water-soluble monodisperse magnetic iron oxide nanoparticles via surface double-exchange with DMSA. Colloids and Surfaces A: Physicochemical and Engineering Aspects. mars 2008;316(1-3):210- 6 .

47. ISO 10993-12:2012(en), Biological evaluation of medical devices - Part 12: Sample preparation and reference materials [Internet]. [cited 2016 Oct 26]. Available from: https://www.iso.org/obp/ui/\#iso:std:53468:en. To estimate that $22 \mu \mathrm{g} / \mathrm{mL}$ corresponds to $6 \mathrm{~cm} 2 \mathrm{per}$ $\mathrm{ml}$, we use the formula: $22 \mu \mathrm{g} / \mathrm{mL}=6 \div(2.21015 \times 12,1510-11)$, where $2.2 \times 1015$ per gram is the number of magnetosomes per gram and $12.15 \times 10-11 \mathrm{~cm} 2$ is the specific magnetosome surface area.

48. Panasci L, Jean-Claude BJ, Vosilescu D, Mustafa A, Damian S, Damian Z, et al. Sensitization to doxorubicin resistance in breast cancer cell lines by tamoxifen and megestrol acetate. Biochemical Pharmacology. 1996;52(7):1097- 102.

49. Rantanen V, Grénman S, Kulmala J, Grénman R. Comparative evaluation of cisplatin and carboplatin sensitivity in endometrial adenocarcinoma cell lines. British journal of cancer. 1994;69(3):482.

50. de Sousa ME, Fernández van Raap MB, Rivas PC, Mendoza Zélis P, Girardin P, Pasquevich GA, et al. Stability and Relaxation Mechanisms of Citric Acid Coated Magnetite Nanoparticles for Magnetic Hyperthermia. The Journal of Physical Chemistry C. 14 mars 2013;117(10):5436- 45.

51. Wilhelm C, Billotey C, Roger J, Pons JN, Bacri J-C, Gazeau F. Intracellular uptake of anionic superparamagnetic nanoparticles as a function of their surface coating. Biomaterials. mars 2003;24(6):1001- 11.

52. Rabin Y. Is intracellular hyperthermia superior to extracellular hyperthermia in the thermal sense? International Journal of Hyperthermia. 1 janv 2002;18(3):194- 202.

53. Jadhav NV, Prasad AI, Kumar A, Mishra R, Dhara S, Babu KR, et al. Synthesis of oleic acid functionalized $\mathrm{Fe} 3 \mathrm{O} 4$ magnetic nanoparticles and studying their interaction with tumor cells for potential hyperthermia applications. Colloids and Surfaces B: Biointerfaces. août 2013;108:158- 68.

54. Alphandéry E, Idbaih A, Adam C, Delattre JY, Schmitt C, Guyot F, Chebbi I, Full intracranial U87Luc tumor disappearance in $100 \%$ of mice bearing these tumors using nonpyrogenic magnetosome minerals coated with poly-L-lysine heated under the application of an alternating magnetic field. Manuscript in preparation. 
Figure 1: TEM images of whole magnetotactic bacteria, IONP, uncoated and coated magnetosome

minerals. (a), Transmission electron microscopy images of a magnetotactic bacterium Magnetospirillum gryphiswaldense used in this study and containing a chain of magnetosomes; (b), chemical nanoparticles IONP; (c), magnetosome minerals without coating, $\mathrm{N}$; (d,e), magnetosome minerals coated with either poly-L-lysine, N-PLL; (f,g), citric acid, N-CA; (h,i), oleic acid, N-OA; (j,k), carboxy-methyl-dextran, $751 \quad$ N-CMD.

Figure 2: Physicochemical properties of uncoated and coated magnetosome minerals.

(a), Size distribution of uncoated magnetosome minerals, measured over 500 magnetosomes. (b),

Weight percentage of carbon and nitrogen in the different nanoparticles, measured by CHNS. (c) and

(d), Variation with time of the absorbance, measured at $480 \mathrm{~nm}$, of suspensions containing of $1 \mathrm{mg} / \mathrm{mL}$

in iron of uncoated, coated magnetosome minerals and IONP. (e) and (f), Variation of Zeta potential of

757 uncoated, coated magnetosome minerals and IONP as a function of $\mathrm{pH}$. These results were obtained

758 from triplicates. The error bars represent standard deviations $\left(\mathrm{SD}^{\circ}\right)$.

759 Figure 3: FTIR spectra of IONP, uncoated and coated magnetosome minerals.

760 Fourier transform infrared, FT-IR spectra of, (a), lyophilized uncoated magnetosome minerals, N; (b),

761 lyophilized IONP; (c), lyophilized magnetosome minerals coated with poly-L-lysine, N-PLL; (d), with 762 citric acid, N-CA; (e), oleic acid, N-OA; (f), carboxy-methyl-dextran, N-CMD.

763 Figure 4: Percentages of 3T3, RG2, and GL-261 cell inhibition in the presence of IONP, uncoated and 764 coated magnetosome minerals.

765 (a), Percentage of $3 \mathrm{~T} 3$ cell inhibition after 24 hours of $3 \mathrm{~T} 3$ cell incubation with various concentrations

766 of uncoated, coated magnetosome minerals and IONP; (b), Percentage of GL-261 cells inhibition after

76724 hours of $3 \mathrm{~T} 3$ cell incubation with various concentrations of uncoated, coated magnetosome minerals 
and IONP; (c), Percentage of GL-261 cell inhibition after 72 hours of 3T3 cell incubation with various

concentrations of uncoated, coated magnetosome minerals and IONP.

770

Figure 5: Heating properties of IONP, uncoated and coated magnetosome minerals, in the presence of GL-261 cells and AMF application.

(a), Variation of temperature of GL-261 cells brought into contact with $1 \mathrm{mg} / \mathrm{mL}$ of uncoated and coated magnetosome minerals and exposed (or not) to an alternating magnetic field of frequency $198 \mathrm{kHz}$ and strength $\mathrm{H}=34 \mathrm{mT}$. (b), Spatial temperature distribution of concentration $1 \mathrm{mg} / \mathrm{ml}$ of N, N-PLL, NCA, N-OA, N-CMD, and IONP mixed with GL-261cells and exposed to an alternating magnetic field of frequency $198 \mathrm{kHz}$ and average field strength of $34 \mathrm{mT}$ during $30 \mathrm{~min}$.

Figure 6: Percentage of cell inhibition and quantity of heat produced by the various nanoparticles under AMF application.

(a), Flow cytometry results showing the percentage of living GL-261 cells treated with or without AMF with uncoated, coated magnetosome minerals and IONP, (b), Spatial temperature distribution within the Petri dish of N, N-PLL, N-CA, N-OA, N-CMD, and IONP mixed with GL-261 cells and exposed to an alternating magnetic field of frequency $198 \mathrm{kHz}$ and average field strength adjusted between 34 and 47 $\mathrm{mT}$ to maintain the temperature of cells mixed with the nanoparticles at $45^{\circ} \mathrm{C}$ during $30 \mathrm{~min}$.

Figure 7: Quantity of iron coming from the various nanoparticles internalized in cells or localized at cell surface after and before AMF application. Quantity of iron per cell (pg) for cells treated with or without AMF.

Table 1: $\Delta \mathrm{T} / \delta \mathrm{t}$ estimated in ${ }^{\circ} \mathrm{C} / \mathrm{s}$; specific absorption rate, estimated in Watt per gram of nanoparticle in iron, temperature variation, and percentage of heated area at $43-46^{\circ} \mathrm{C}$ for uncoated, coated magnetosome minerals and IONP brought into contact with GL-261 cells and exposed to an alternating magnetic field of $198 \mathrm{kHz}$ and strength $32 \mathrm{mT}$ applied during 30 minutes. 
791 Table 2: Percentage of heated area at $43-46^{\circ} \mathrm{C}$ for uncoated, coated magnetosome minerals and IONP 792 mixed with GL-261 cells and exposed to an alternating magnetic field of $198 \mathrm{kHz}$ and strength of $32 \mathrm{mT}$ 793 applied during 30 minutes.

794 


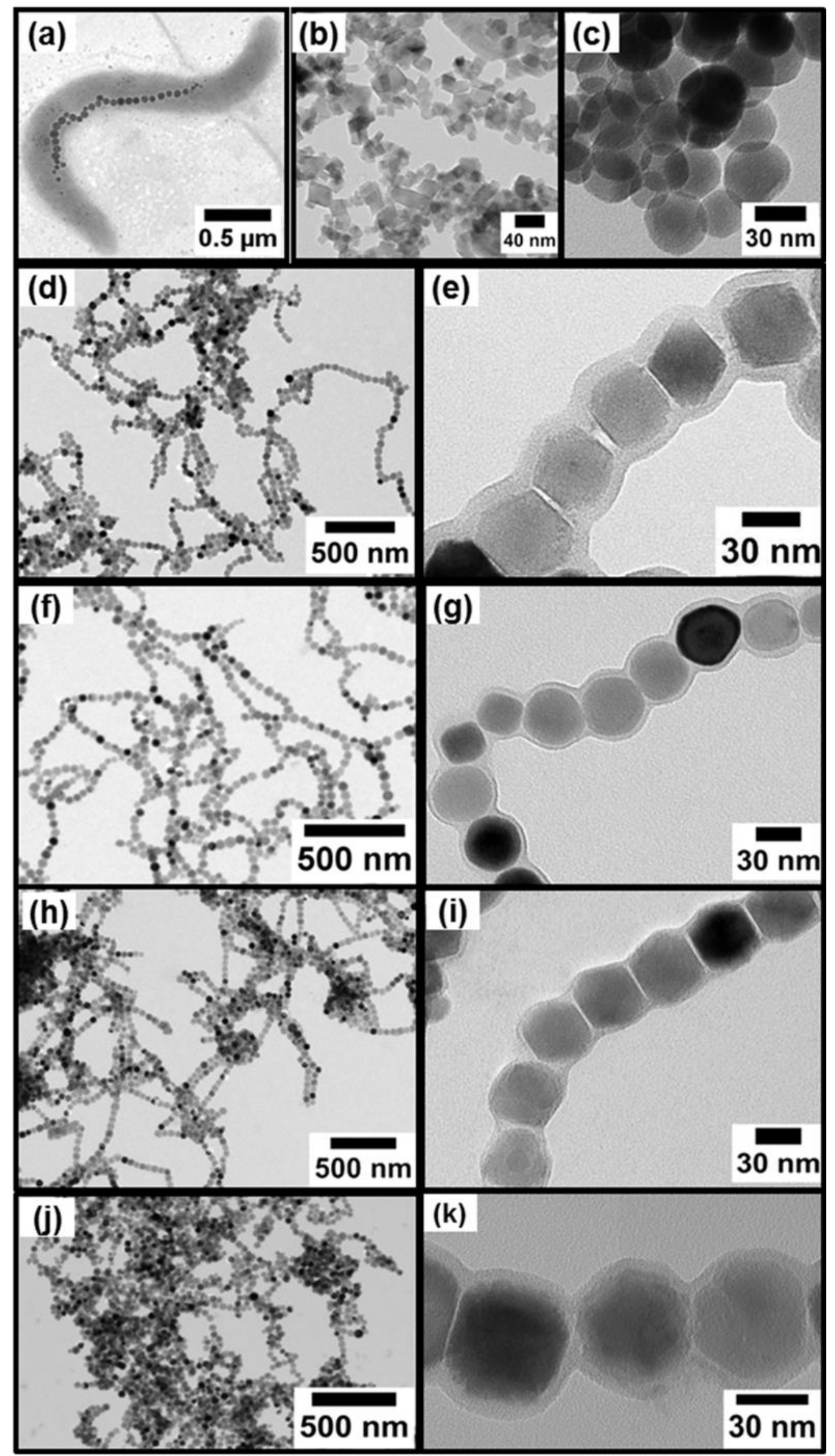

Figure 1 


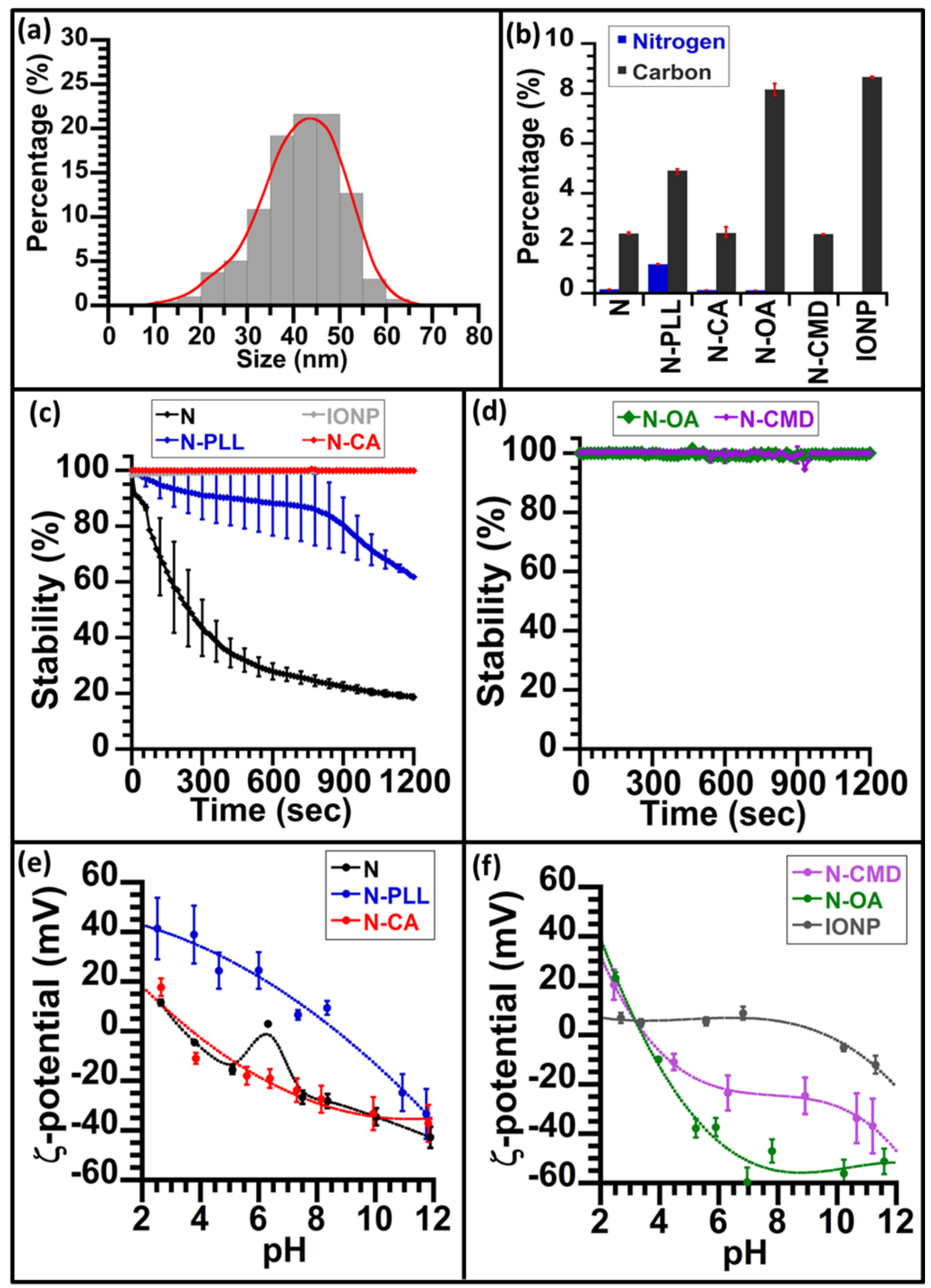

Figure 2 


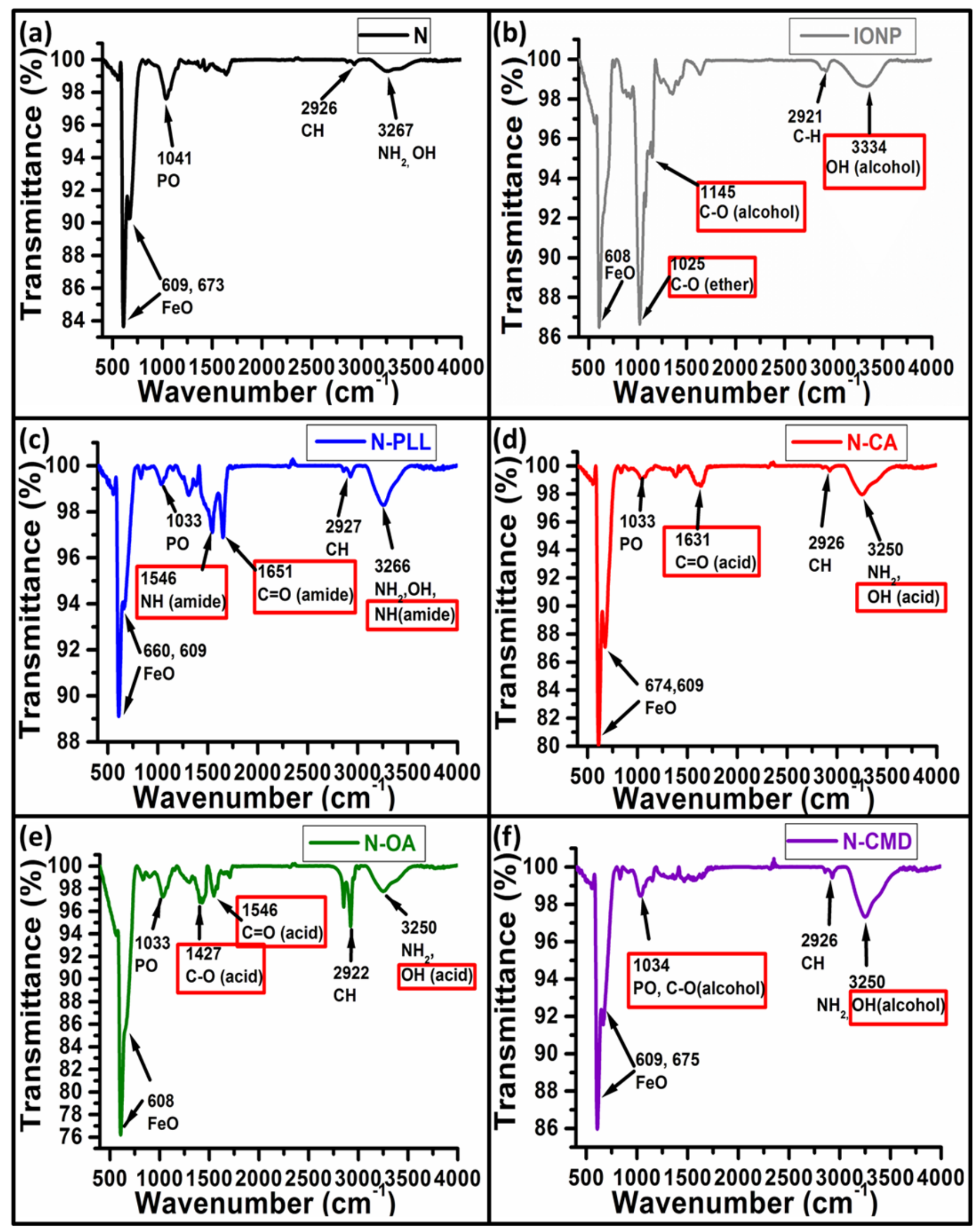

Figure 3 


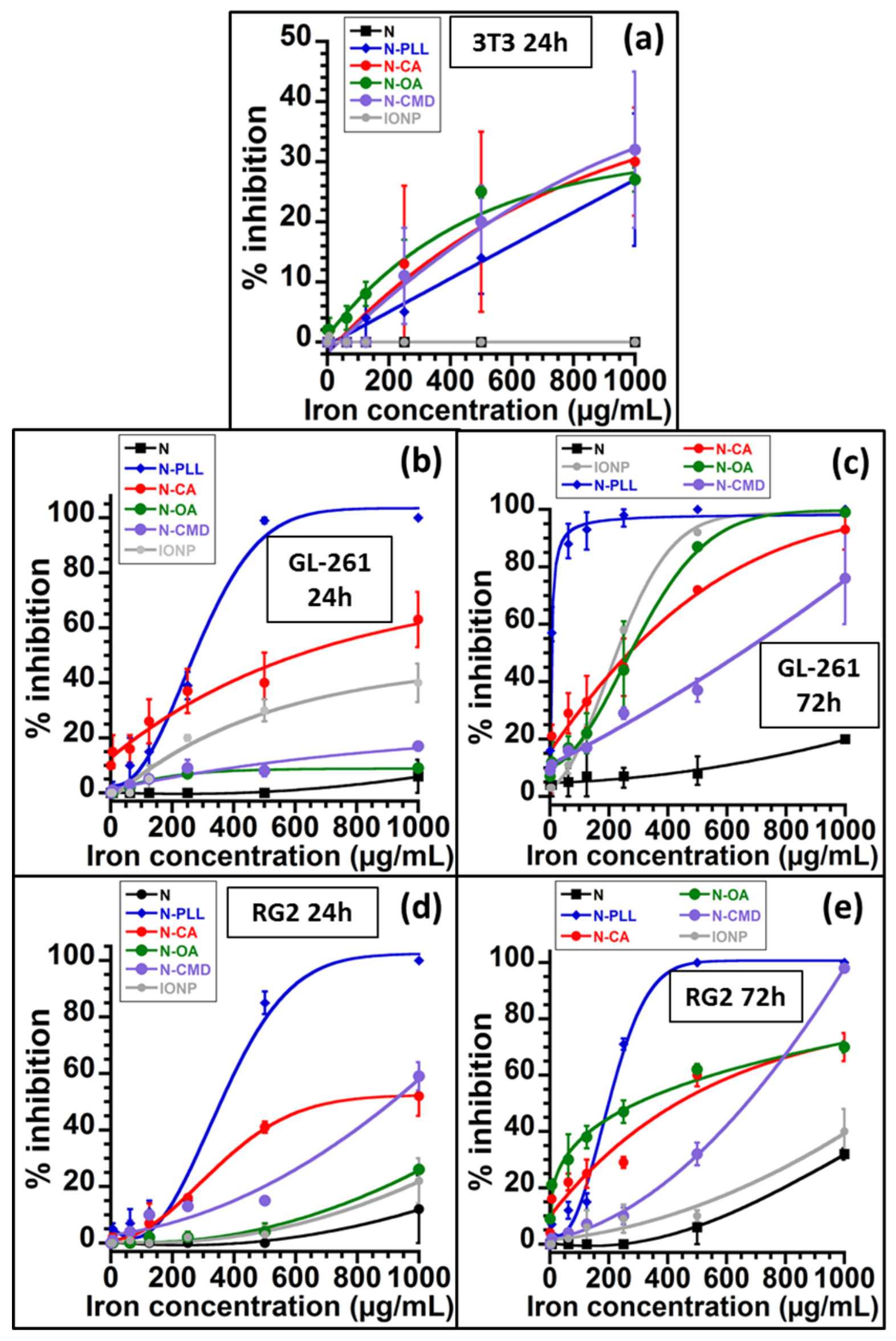

Figure 4 


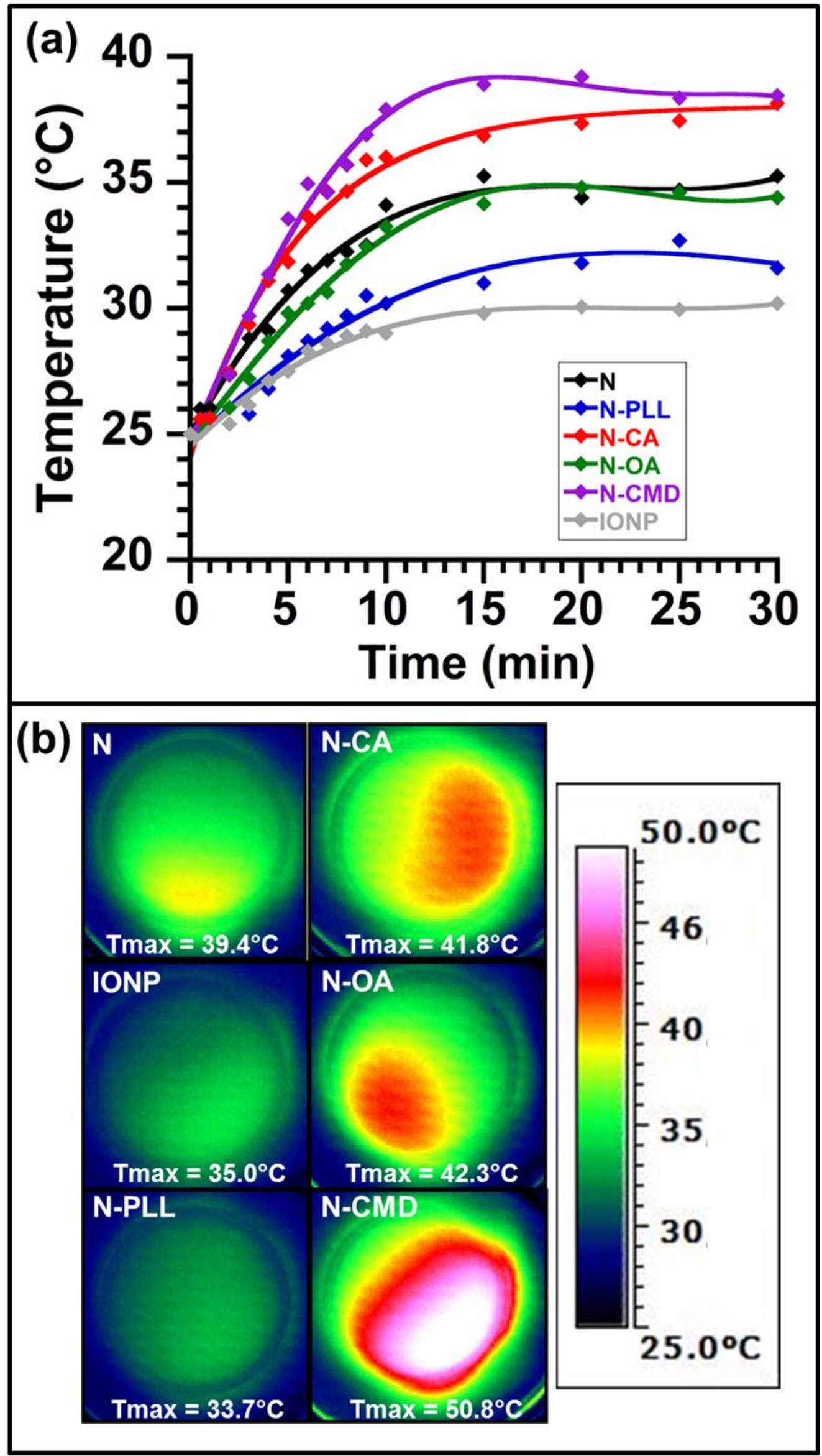

Figure 5 


\begin{tabular}{|c|c|c|c|}
\hline \multicolumn{2}{|c|}{$\begin{array}{c}\Delta T / \delta \mathrm{t} \\
\left({ }^{\circ} \mathrm{C} / \mathrm{s}\right)\end{array}$} & $\begin{array}{c}\text { SAR } \\
(\mathrm{W} / \mathrm{g} \text { of iron })\end{array}$ & $\begin{array}{c}\text { Percentage of } \\
\text { heated area } \\
\text { at } 43-46^{\circ} \mathrm{C} \\
(\%)\end{array}$ \\
\hline N & $2.30 \mathrm{E}-02$ & 96 & 0.0 \\
\hline IONP & $1.80 \mathrm{E}-02$ & 73 & 0.0 \\
\hline N-PLL & $2.10 \mathrm{E}-02$ & 89 & 0.0 \\
\hline N-CA & $3.40 \mathrm{E}-02$ & 141 & 12.7 \\
\hline N-OA & $2.40 \mathrm{E}-02$ & 100 & 12.4 \\
\hline N-CMD & $4.70 \mathrm{E}-02$ & 196 & 90.1 \\
\hline
\end{tabular}

\section{Table 1}

800 


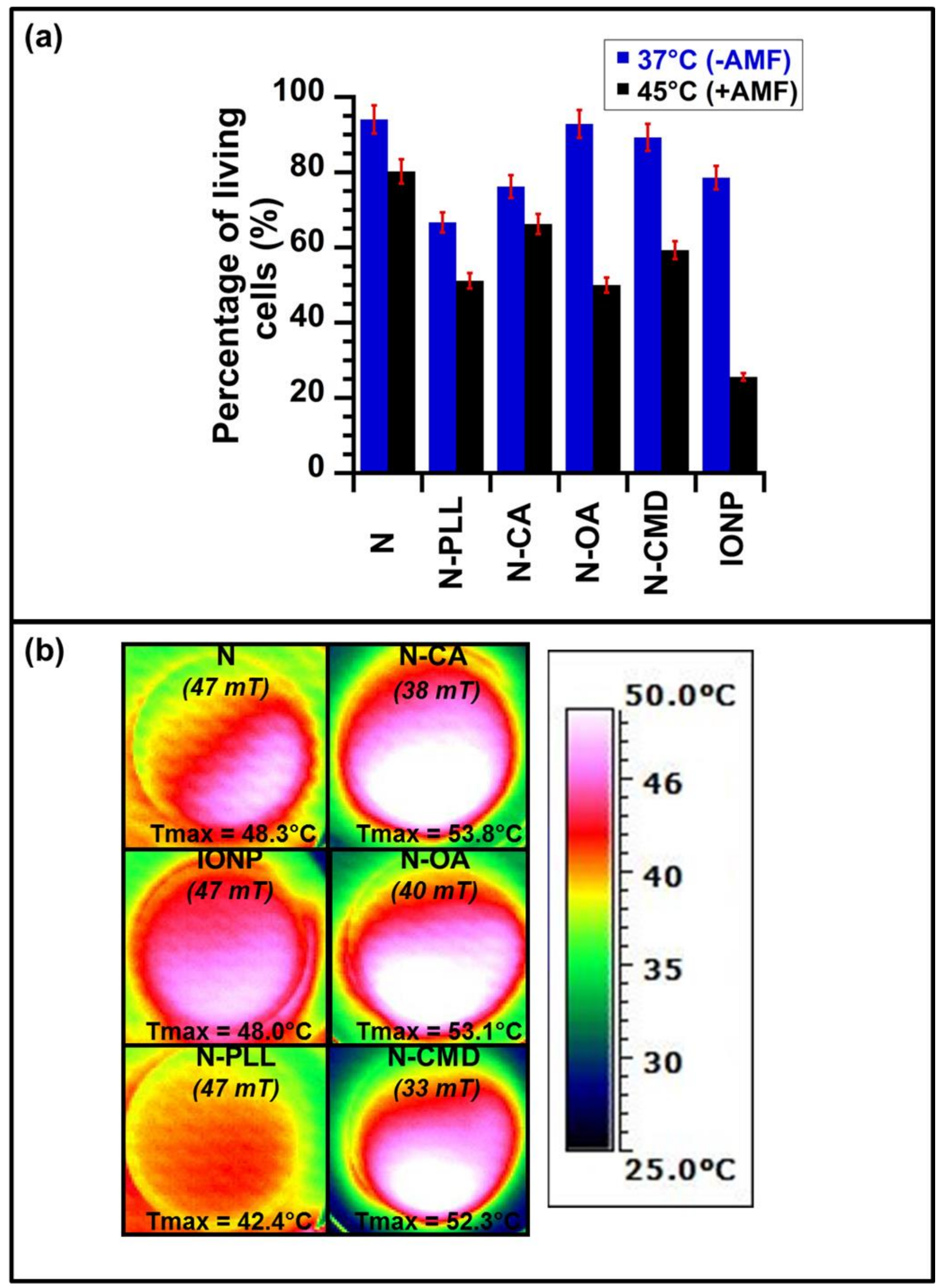

Figure 6 


\begin{tabular}{|c|c|}
\hline & $\begin{array}{c}\text { Percentage of heated area } \\
\text { at } 43-46^{\circ} \mathrm{C} \\
\text { (\%) }\end{array}$ \\
\hline $\mathbf{N}$ & 89.4 \\
\hline IONP & 100.0 \\
\hline N-PLL & 32.0 \\
\hline N-CA & 100.0 \\
\hline N-OA & 100.0 \\
\hline N-CMD & 100.0 \\
\hline
\end{tabular}

Table 2

802 


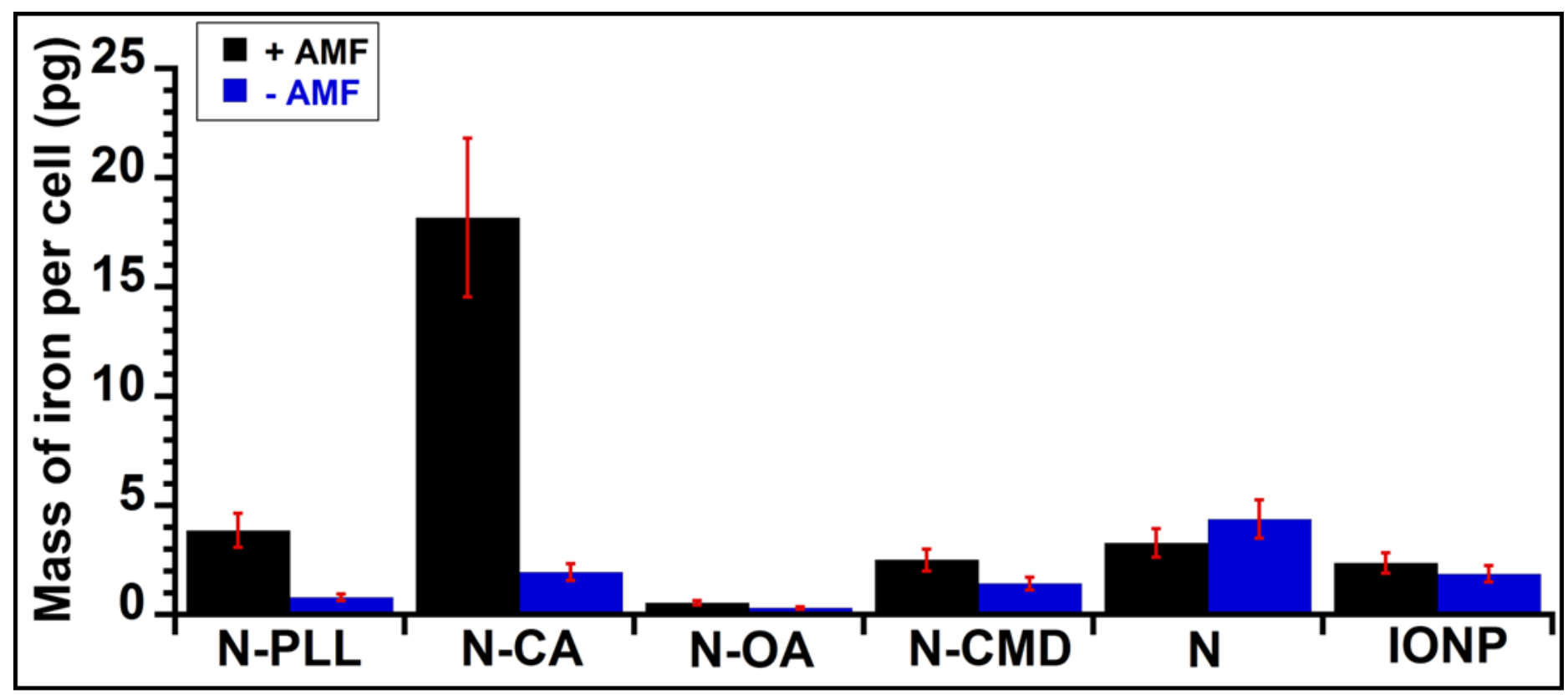

Figure 7

803

804

805

806

807 